\title{
COMPORTAMENTO CLÍNICO DE CIMENTOS DE IONÔMERO DE VIDRO UTILIZADOS COMO SELANTE OCLUSAL POR MEIO DA TÉCNICA DO TRATAMENTO RESTAURADOR ATRAUMÁTICO (ART)
}

ANA LUIZA FALAVINHA VIEIRA

Tese apresentada à Faculdade de Odontologia de Bauru, da Universidade de São Paulo, como parte dos requisitos para obtenção do título de Doutor em Odontologia, área de Odontopediatria.

(Edição Revisada) 


\section{COMPORTAMENTO CLÍNICO DE CIMENTOS DE IONÔMERO DE VIDRO UTILIZADOS COMO SELANTE OCLUSAL POR MEIO DA TÉCNICA DO TRATAMENTO RESTAURADOR ATRAUMÁTICO (ART)}

ANA LUIZA FALAVINHA VIEIRA

Tese apresentada à Faculdade de Odontologia de Bauru, da Universidade de São Paulo, como parte dos requisitos para obtenção do título de Doutor em Odontologia, área Odontopediatria.

(Edição Revisada)

Orientadora: $\operatorname{Prof}^{\mathrm{a}} \mathrm{Dr}^{\mathrm{a}}$ Maria Aparecida de Andrade Moreira Machado 


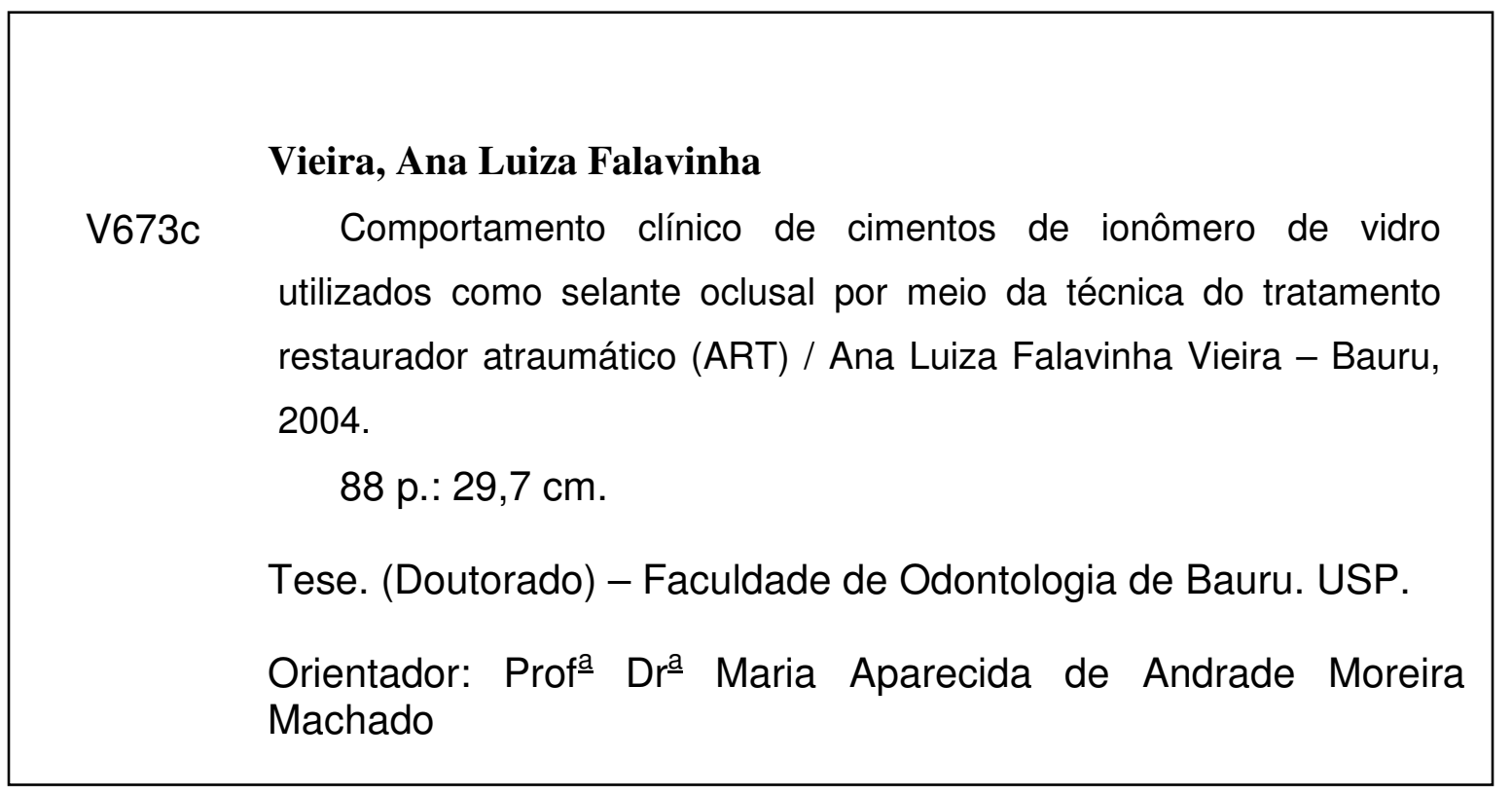

Autorizo, exclusivamente para fins acadêmicos e científicos, a reprodução total ou parcial desta dissertação, por processos fotocopiadores e outros meios eletrônicos.

Assinatura do autor:

Data: / $/ 04$

Aprovação pelo Comitê de Ética em Pesquisa da FOB obtida em 30/11/2000. 


\section{ANA LUIZA FALAVINHA VIEIRA}

18 de dezembro de 1975

Lençóis Paulista - SP

$1994-1997$

$1998-2000$

1999

$2001-2004$

Associações
Nascimento

Curso de Odontologia - Faculdade de Odontologia de Bauru - Bauru - SP

Curso de Pós-Graduação em Odontopediatria, em nível de Mestrado, na Faculdade de Odontologia de Bauru, USP.

Professora Assistente I da disciplina de Odontopediatria e Ortodontia, na Faculdade de Odontologia da Universidade Paulista, campus Bauru.

Curso de Pós-Graduação em Odontopediatria, em nível de Doutorado, na Faculdade de Odontologia de Bauru, USP.

APCD - Associação Paulista de Cirurgiões Dentistas

CRO - Conselho Regional de Odontologia IADR - International Association for Dental Research

SBPqO - Sociedade Brasileira de Pesquisa Odontológica 


\section{SUMÁRIO}

LISTA DE ABREVIATURAS ..........................................

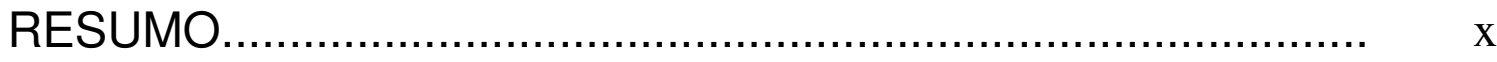

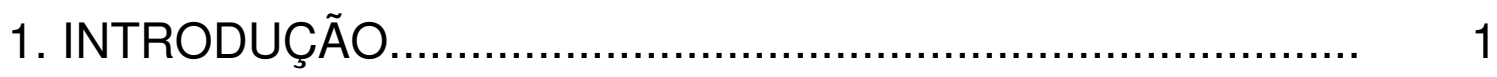

2. REVISÃO DE LITERATURA.......................................... 5

2.1 - Tratamento Restaurador Atraumático .......................... 6

2.2 - Cimentos de lonômero de Vidro.................................. 9

2.3 - Selamento das superfícies oclusais com CIV ............... 16

2.4 - Selamento das superfícies oclusais com CIV no contexto do ART.

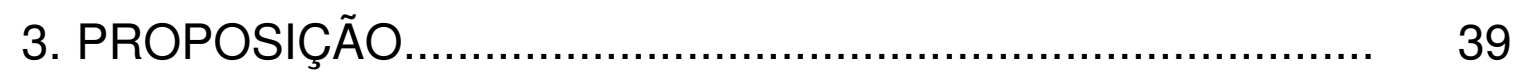

4. MATERIAL E MÉTODOS............................................... 41

5. RESULTADOS .......................................................... 51

6. DISCUSSÃO ............................................................ 57

7. CONCLUSÕES ............................................................ 66

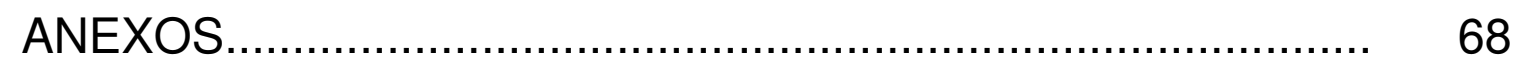

REFERÊNCIAS BIBLIOGRÁFICAS.................................... 74

ABSTRACT ................................................................ 87 


\section{LISTA DE ABREVIATURAS}

ART - Atraumatic Restorative Treatment ou Tratamento

Restaurador Atraumático

CD - Cirurgião-dentista

CIV - cimento de ionômero de vidro

ESALQ - Escola Superior de Agronomia Luiz de Queiróz

FOB - Faculdade de Odontologia de Bauru

IADR - International Association for Dental Research

IPV - índice de placa visível

ISG - índice de sangramento gengival

MEV - Microscópio Eletrônico de Varredura

PT - perda total

RC's - resinas compostas

$\mathbf{R T}$ - retenção total

$\mathbf{R P}$ - retenção parcial

THD - técnico em higiene dentária

USP - Universidade de São Paulo 
A Dens,

Obrigada Senhor por me dar tantos motivos para agradecer... 
"O lar é o que conhecemos e amamos.

Quando estamos juntos, estamos em casa.

O lar não é um lugar. Não creío que o conhecido

e o amado... estejam presos com pregos,

nem que tenham teto e alicerces.

O lar é uma certa estrutura que nos é cara,

Onde não há perigo em ser quem somos."

Richard Bach

À minha filha Laura,

Ao meu companheiro Eduardo

Aos meus pais, Lucimar e Jorge

À minhas irmãs, Carô e Ciça

AGRADEÇO IMENSAMENTE E DEDICO ESTE TRABALHO 
À minha orientadora, Profa. Dra. Maria Aparecida de Andrade Moreira Machado pelo incentivo e reconhecimento, petas portas sempre abertas...

Meus sinceros agradecimentos. 


\section{AGRADEÇO ESPECIALMENTE}

A Profa. Dra. Maria Fidela de Lima Navarro, um exemplo de honestidade e coragem. Obrigada por tudo, do fundodo coração.

A Profa. Dra. Salete Moura Bonifácio da Silva, que como sew exemplo sempre nos incentiva a querer saber mais. Uma pessoa extremamente humana e amiga.

Aos professores da disciplina de Odontopediatría da Faculdade de Odontologia de Baurw, Prof. Dr. Aymar Pavarini, Prof. Dr. Bernardo Gonzalez Vono, Prof. Dr. José Eduardo de Oliveira Lima, Profa. Dra. Maria Francisca Thereza Borro Býjella, Prof. Dr. Ruy César Camargo Abdo, que muito contribuiram para que ew me tornasse uma Odontopediatra.

Aos funcionários da discíplina de Odontopediatría da Faculdade de Odontologia de Bauru, Fátima, D. Lía, Lilian, Maria Estela pela amizade, carinho e colaboração em todos os momentos.

Aos amigos Cleide e Cadiu, por estarem sempre prontos a ajudar e como ajudam... 
A amiga Daniela Rios, que está sempre por perto com uma palavra de incentivo.

A Livia pela amizade de longa data.

Aos amigos do curso de Doutorado, Cleide, José Vitor, Maria Fernanda e Patoma.

As colegas da disciplina de Odontopediatria e Ortodontia da UNIP, Ana Cláudia, Daniela, Maria Lígia. e em especial a Nildinha que me convidow para participar deste trabatho que hoje se transforma na minha tese de Doutorado.

A Terezinha, uma pessoa prestimosa e sempre disposta a ajudar no que for necessário, obrigada pela colaboração na reatização das avatiações.

A Celiane, que me emprestow $\sigma$ material e ajudow na confecção das réplicas.

Aos pacientes e seus responsáveis, pela colaboração e boa vontade, sem as quais este trabalho se tornaria inviável.

Aos diretores e funcionários de todas as escolas de Bauru por onde este trabalho me levow, pessoas que sempre me receberam com muito boa vontade. 
Ao Prof. Dr. Kitajima e todos os outros funcionários do NAP/MEPA da ESALQ/USP, por me permitirem usar as dependências deste laboratórío e me ajudarem na análise da minha amostra. 


\section{AGRADEÇO AINDA,}

À Faculdade de Odontologia de Bauru - FOB-da Universidade de São Paulo, através de sua diretora Profa. Dra. Maria Fidela de Lima Navarro e do presidente da Comissão de Pós-Graduação Prof. Dr. José Carlos Pereira.

Aos funcionários da Faculdade de Odontologia de Bauru, em especial aos da seção de Pós-Graduação, pela orientação, eficiência e atenção e aos da Büblioteca, pela dedicação e paciência com que reatizam seu trabalho e pela atenção que dispensam a todos os alunos.

E a todos, que de uma maneira ou de outra, não menos importante, contribuiram para realização deste trabalho. 
RESUMO 


\section{RESUMO}

O objetivo deste trabalho foi avaliar o índice de retenção e o efeito preventivo de selamentos realizados pela técnica do Tratamento Restaurador Atraumático em 1 os molares permanentes recém-erupcionados de pacientes de uma comunidade com alto índice de cárie. Foram realizados 74 selamentos com ChemFlex (CIV de alta viscosidade) e 76 com Vidrion R (CIV restaurador convencional) em 42 crianças de 6-8 anos de idade. Os selamentos foram realizados por apenas um cirurgião-dentista pela técnica da pressão digital, em uma escola pública da cidade de Bauru - SP. A avaliação dos mesmos foi realizada por outros 2 cirurgiões-dentistas calibrados por meio de avaliações clínicas e fotográficas. A perda da amostra nos controles de 12 e 36 meses foi de $9,3 \%$ e $11,7 \%$, respectivamente. Depois de 12 meses, $41,8 \%$ dos selantes de ChemFlex e $43,8 \%$ dos de Vidrion R estavam parcial ou totalmente retidos. Dos dentes inicialmente selados, 1,5\% encontraram-se restaurados e $98,5 \%$ estavam livres de cárie. $\mathrm{Na}$ avaliação de 36 meses, a retenção parcial foi de 24,6\% para o ChemFlex e 20,9\% para o Vidrion R e $9,2 \%$ dos selantes de ChemFlex e $9 \%$ dos de Vidrion R foram substituídos por outro tratamento. Das superfícies seladas com Chem Flex 3,1\% desenvolveram cárie. O índice de sucesso aos 36 meses foi de 93,7\%. Os testes estatísticos Qui-quadrado e Mann-Whitney $(p<0,01)$ mostraram não haver diferença significativa tanto na retenção quanto no efeito preventivo dos materiais testados. Os resultados obtidos sugerem que apesar dos baixos índices de retenção, o selamento de molares recém-erupcionados através da técnica do ART pode ser considerado um tratamento preventivo em crianças com alto índice de cárie. 


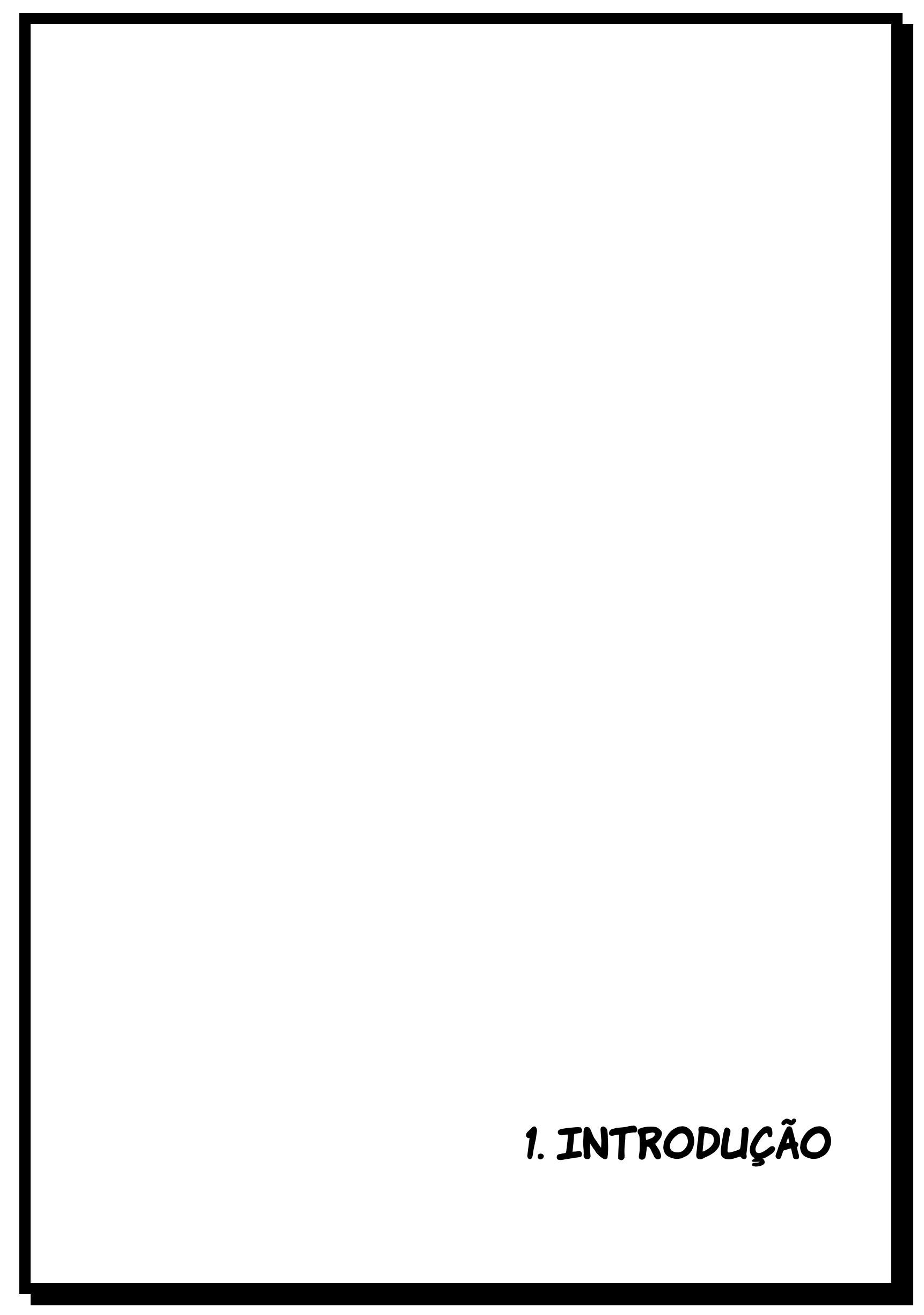




\section{INTRODUÇÃO}

Embora a cárie dental esteja em declínio na maioria dos países desenvolvidos, ela continua a ser a doença bucal mais prevalente em seres humanos. Segundo a Organização Mundial da Saúde, a cárie dentária atinge entre 50 e $99 \%$ das pessoas em todas as comunidades (WHO: Oral Health) ${ }^{91}$. Em países em desenvolvimento, sua incidência não diminuiu significativamente e o seu tratamento na maioria das vezes não é realizado devido à falta de condições financeiras por parte dos pacientes e dos governos para a realização do tratamento convencional (FRENCKEN; MANJI; MOSHA ${ }^{31}, 1986$, CHIRONGA, MANJI ${ }^{15}$, 1989; MATTHESEN et al. ${ }^{54}$, 1990; ADDO-YOBO; WILLIANS; CURZON² ${ }^{2}$ 1991). No Brasil, CALDAS; MARCENES; SHEIHAM ${ }^{13}$ (2000) avaliaram as razões pelas quais os dentes eram extraídos e encontraram que para $70,3 \%$ deles a causa desta indicação foi a cárie e suas seqüelas.

Com o intuito de mudar esta realidade, várias estratégias têm sido propostas e estudadas. Recentemente uma nova técnica foi introduzida por PILOT visando o atendimento de pacientes sem acesso à assistência odontológica convencional imediata. Esta técnica está fundamentada em um programa realizado na Tanzânia por FRENCKEN na década de 80 e é conhecida como Atraumatic Restorative Treatment (ART) ou Tratamento Restaurador Atraumático. Este tratamento é baseado na escavação do tecido cariado com a utilização de instrumentos manuais, seguido da restauração da cavidade resultante com cimento de ionômero de vidro (FRENCKEN et al. ${ }^{25}$, 1997, FRENCKEN; HOLMGREN²7, 1999). Além de restauradora, esta técnica 
também tem uma abordagem preventiva: todas as fossas e fissuras adjacentes são seladas com o mesmo material ${ }^{28}$, além da orientação sobre cuidados com a Saúde Bucal que é fornecida a todos pacientes incluídos no programa. O ART é uma das prioridades no Programa de Cuidados Bucais em países em desenvolvimento ${ }^{37}$.

Selantes oclusais resinosos têm sido utilizados com sucesso há mais de 40 anos $^{8,59}$. Eles são indicados em fossas e fissuras nas seguintes condições clínicas: cárie restrita ao esmalte, quando as fossas e fissuras são profundas e em pacientes com alto risco à cárie. Os selantes agem como barreiras físicas que isolam as fossas e fissuras do ambiente bucal, prevenindo que a placa dentária se acumule e o processo de cárie se inicie ${ }^{95}$. Em 1974 foi sugerido o uso do cimento de ionômero de vidro convencional (Mc LEAN; WILSON ${ }^{57}$, 1974) para essa finalidade, por ser um material com boas propriedades físicoquímicas, entre as quais a liberação de flúor e a adesão ao esmalte e à dentina (STRAFFON; DENNISON; MORE ${ }^{84}$, 1985). A partir de então vários estudos vêm sendo desenvolvidos com o intuito de avaliar a eficácia deste tipo de selante, tanto em relação à retenção quanto em relação à prevenção de cárie.

Apesar de os índices de retenção dos selantes ionoméricos serem conflitantes na literatura existente ${ }^{6,12,55,59,89}$, trabalhos como o de ARROW; RIORDAN $^{8}$ (1995) , e o de REUTERVING; DIJKEN ${ }^{73}$ (1995) , mostram que a retenção do ionômero não é um pré-requisito para a prevenção de cáries, pois o seu efeito preventivo se prolonga mesmo após o selante ser perdido, devido à liberação de flúor continuada que o material oferece quando está sobre o dente, favorecendo a maturação do esmalte dos dentes recém irrompidos, tornando-os resistentes ao ataque ácido das bactérias. 
Em 1994, FRENCKEN et al. ${ }^{23}$ relataram o resultado de um estudo que avaliou clinicamente a performance de selamentos realizados através da técnica ART no Zimbábue. Neste estudo foi utilizado o ionômero ChemFil Superior/ESPE. Em $1996^{29}$ e $1998^{26}$ foram publicados respectivamente os resultados de um e três anos e a porcentagem de selamentos total ou parcialmente retidos foi de $73,7 \%$ e $46,6 \%$ respectivamente. Em outro estudo ${ }^{30}$ realizado com Fuji IX (cimento de ionômero de vidro de alta viscosidade), a porcentagem de selamentos total ou parcialmente retidos após 3 anos subiu para $71,4 \%$. Este resultado sugeriu que materiais de alta viscosidade apresentam melhores características do que os convencionais. Por outro lado o custo destes materiais também é mais elevado quando comparado aos convencionais.

Vários autores reportam sucesso em prevenir cárie através da aplicação dos selantes realizados pela Técnica Restauradora Atraumática (ART). Estes trabalhos foram realizados em pacientes com baixo índice CPOD, variando de 0,6 (HOLMGREN et al. ${ }^{41}$, 2000) a 1,1 (FRENCKEN et al. ${ }^{26}$, 1998) e em pacientes com idade média de 12-13 $\operatorname{anos}^{26,29,30,41}$. Há falta de dados com relação ao comportamento dos selamentos realizados através da técnica ART em populações com alta experiência de cárie. Desta forma o estudo do emprego do CIV para o selamento através da técnica do ART merece ainda estudos longitudinais, sobretudo para uma faixa da população onde a incidência de cárie é elevada. A perspectiva de um efeito preventivo utilizando uma técnica simples e efetiva é o desafio e a constante busca dos que praticam a Odontopediatria. 
2. REVISÃO DE LITERATURA 


\section{REVISÃO DE LITERATURA}

Este capítulo está subdividido em tópicos para facilitar o entendimento do tema abordado neste estudo.

\section{1 - TRATAMENTO RESTAURADOR ATRAUMÁTICO}

O Tratamento Restaurador Atraumático foi inicialmente desenvolvido como resposta à necessidade de se encontrar um método que preservasse dentes cariados de pessoas de todas as idades, tanto em países em desenvolvimento quanto em comunidades em que os recursos para o tratamento odontológico convencional eram insuficientes. Sem este tipo de intervenção, estes dentes provavelmente seriam extraídos pela própria progressão da lesão, tornando a extração dentária uma regra do tratamento odontológico e não uma exceção.

O nome da técnica sugere que a mesma não causa nenhum tipo de trauma, mas no contexto do ART isto significa: menor desconforto ao paciente, maior conservação do tecido dentário sadio e acima de tudo a tentativa de preservar o órgão dentário ${ }^{4}$.

Este tipo de tratamento surgiu de observações num programa de prevenção realizado na Tanzânia ${ }^{27}$, no qual as lesões de cárie das crianças participantes só aumentavam de ano para ano e nenhuma intervenção curativa era realizada. Então, com a necessidade não só do tratamento preventivo, mas também do restaurador, os autores resolveram escavar as lesões somente com instrumentos manuais e restaurar a cavidade resultante deste processo com um cimento de policarboxilato, devido a suas propriedades adesivas. Esse 
procedimento estava baseado na intervenção mínima, que preconiza somente a remoção de dentina infectada, deixando-se assim, a dentina afetada passível de remineralização. Depois de 9 meses, foi observado que todas as restaurações estavam presentes, porém com um alto grau de desgaste e que somente um dente teve de ser extraído.

Esses resultados estimularam o aprimoramento da técnica substituindo o cimento de policarboxilato pelo cimento de ionômero de vidro, devido à superioridade das propriedades físicas deste último. Os cimentos de ionômero de vidro (CIV) utilizados foram os restauradores convencionais, ou seja, com ativação química através da reação ácido-base.

A utilização de instrumentos manuais e materiais restauradores adesivos não representava novidade, porém, o potencial oferecido pela combinação destes dois elementos ainda não tinha sido estudado anteriormente ${ }^{27}$.

A partir de vários trabalhos apresentados em congressos, especialmente nas sessões gerais da $\operatorname{IADR}^{40,43,45}$, a técnica foi reconhecida pela OMS em $1994^{90}$, durante o dia mundial da Saúde em Genebra. A partir deste dia, a OMS incluiu um programa de cuidados bucais que engloba o desenvolvimento, a verificação do sucesso e a disseminação da técnica do ART por várias regiões do mundo. Esta entidade, juntamente com uma universidade da Holanda desenvolveu um manual ${ }^{25}$ sobre ART no qual constam informações sobre o desenvolvimento da cárie, os princípios da Intervenção Mínima, os passos do ART, a avaliação da técnica e um capítulo sobre CIV. Em 1995, um simpósio sobre ART foi realizado no encontro da IADR em Cingapura $^{68}$ e resultou em um volume especial do Journal of Public Health Dentistry (v.56, n.3). Mais tarde, em 1999, um livro $^{27}$ dos mesmos professores desta 
universidade da Holanda, foi lançado com o propósito de difundir a técnica entre cirurgiões-dentistas (CD’s), técnicos em higiene dentária (THD’s), auxiliares odontológicos e agentes comunitários de várias partes do mundo. Há também um site dentro da página oficial da $\mathrm{OMS}^{39,91}$, que fornece informações sobre a técnica. Neste site, pode-se fazer um cadastro para receber estas informações por e-mail.

A técnica do ART descrita neste manual ${ }^{25}$ e neste livro ${ }^{27}$ relata todos os passos desde a promoção de saúde bucal, passando pela técnica operatória, até os métodos de avaliação da técnica. Nesta etapa torna-se importante ressaltar os passos operatórios para a realização de selamentos e restaurações, uma vez que se trata do ponto diferencial da técnica e segundo o manual, os dois princípios mais importantes são a remoção de tecido cariado utilizando somente instrumentos manuais e a restauração da cavidade com um material adesivo.

O passo a passo da técnica restauradora pode ser encontrado detalhadamente no manual da $\mathrm{OMS}^{25}$, bem como em outras fontes ${ }^{24,27}$. A seqüência para realização do selamento de fossas e fissuras, também presente no manual $^{25}$ será detalhadamente descrita no capítulo Material e Métodos desta tese.

A literatura científica sobre ART começou com FRENCKEN et al. ${ }^{23} \mathrm{em}$ 1994, relatando a aceitabilidade da técnica e a longevidade de restaurações e selamentos. Avaliando-se a técnica do ART em comparação com o tratamento convencional, PHANTUMVANIT et al. ${ }^{66}$ em 1996, encontraram uma diferença estatisticamente significante em favor da técnica convencional. Apesar desta diferença, os autores concluíram que os índices de sucesso do ART foram 
promissores e encorajadores para o aprimoramento da técnica. Desde então, vários outros trabalhos foram publicados com resultados satisfatórios ${ }^{23,26,29,30,41}$ mostrando que o ART constitui uma opção de tratamento odontológico àqueles que não têm acesso ao tratamento convencional. Além do fator econômico, outros fatores podem afastar as pessoas de um consultório odontológico, como no caso de pacientes ansiosos, pacientes com problemas médicos ou psíquicos, pacientes acamados ou institucionalizados, e nestes casos o ART se torna uma opção viável ${ }^{17}$.

Um exemplo da efetividade deste tratamento está no estudo de MICKENAUTSCH et al. ${ }^{60}$ (1999). Depois da implementação do ART em uma comunidade da África do Sul, os autores verificaram que o número de dentes extraídos foi reduzido em 17,4\%, o componente "restaurado" do CPOD aumentou em $33,4 \%$ e o tratamento odontológico se tornou mais preventivo e menos desagradável ao paciente.

\section{2 - CIMENTOS DE IONÔMERO DE VIDRO}

O cimento de ionômero de vidro (CIV), também denominado cimento ionomérico ou cimento de polialcenoato de vidro, foi desenvolvido por WILSON; KENT ${ }^{93}$ em 1971, numa tentativa de unir no mesmo material a capacidade de liberação de flúor dos cimentos de silicato e a biocompatibilidade e adesividade dos cimentos de policarboxilato. Foi primeiramente comercializado na Europa em 1975, sofrendo desde então um constante aprimoramento nas suas propriedades, ocupando um lugar de destaque entre os materiais dentários, sendo utilizado em diversos ramos da 
Odontologia moderna e possibilitando o emprego de técnicas restauradoras ainda mais conservadoras.

No ano de 1983, SIMMONS ${ }^{76}$ adicionou o pó da liga de amálgama ao pó do ionômero de vidro, formando a chamada "mistura milagrosa", com a finalidade de melhorar suas propriedades mecânicas de resistência à abrasão e à fratura e conferir radiopacidade ao material.

Com o mesmo intuito, em 1985 MCLEAN; GASSER $^{56}$ desenvolveram o ionômero de vidro "cermet", no qual, partículas metálicas são unidas ao pó do ionômero através da sinterização em altas temperaturas, conferindo além da melhora nas propriedades mecânicas, maior densidade, menor solubilidade aos fluidos bucais e menor porosidade quando comparado ao CIV convencional.

Em 1989 surgiram os CIV modificados por resina. Esses materiais contêm monômeros resinosos que permitem uma ativação da polimerização através de luz halógena. As propriedades físicas desses cimentos são superiores às dos convencionais e ainda exibem as vantagens de um tempo de trabalho controlado, facilidade de manipulação (técnica menos sensível) e um rápido endurecimento, minimizando os problemas de sensibilidade ao acabamento imediato e de ressecamento, comuns aos cimentos convencionais. Esses materiais preservam as vantagens clínicas dos CIV convencionais em relação à redução da microinfiltração, adesão química ao esmalte e à dentina, compatibilidade pulpar e liberação de íons flúor.

Com o surgimento do $\mathrm{ART}^{23}$ e com os resultados da avaliação da técnica se mostrando inferiores aos do tratamento convencional e, segundo alguns autores sendo a principal falha da técnica relacionada às propriedades físicas 
dos CIV convencionais, começaram a surgir no mercado os CIV de alta viscosidade, com propriedades físicas melhoradas, especialmente desenvolvidos para esta técnica.

Segundo GUGGENBERG; MAY; STEFAN ${ }^{34}$ (1998), existem três maneiras de se melhorar as propriedades físicas de um CIV: aumentando a proporção pó/líquido, aumentando o peso molecular do poliácido ou aumentando a concentração do mesmo. Estas modificações referentes ao ácido também requerem adaptações no pó. Então, as partículas desses CIV de alta viscosidade se apresentam geralmente menores e em maior número.

Apesar de as propriedades físicas ainda não serem ideais, os CIV foram o material de escolha para a técnica do ART pois possuem outras qualidades que favorecem sua utilização. Dentre elas pode-se citar: reação química de ativação, adesividade às estruturas dentárias, biocompatibilidade, coeficiente de expansão térmica linear próximo ao do dente e liberação de flúor.

EWOLDSEN; COVEY; LAVIN ${ }^{19}$ (1997) estudaram a resistência à compressão, à tração e a adesão ao esmalte e a dentina de diferentes CIV. Foram avaliados: Fuji IX/GC (CIV de alta viscosidade), Fuji Plus/GC e Advance/L.D.Caulk (CIV modificados por resina). O material com maior resistência à compressão foi o Fuji IX, enquanto que nos outros testes os CIV modificados por resina manipulados com maior proporção pó-líquido mostraram valores superiores. Os autores concluíram que existe a necessidade de mais estudos com os CIV modificados por resina manipulados em maior proporção pó-líquido utilizados no ART.

A adesividade é uma característica importante, senão a mais importante, para a indicação deste material na técnica ART. O ionômero apresenta união 
química à estrutura dentária proveniente da quelação dos grupos carboxílicos dos poliácidos com o cálcio existente na apatita do esmalte e da dentina, sendo que devido ao maior componente mineral do esmalte, neste a força de união é maior. A superfície a ser restaurada com CIV deve ser condicionada para uma melhor adesão, e o uso do ácido poliacrílico a 10\% por 10 segundos é o mais indicado $^{18,62}$. Este muda a energia de superfície e aumenta a capacidade de molhamento, melhorando a adaptação do material.

O provável mecanismo de adesão ao dente dos cimentos convencionais é teoricamente baseado em um processo dinâmico de trocas iônicas. O ácido poliacrílico irá penetrar nas estruturas dentárias, quebrando a ligação iônica da hidroxiapatita e conseqüentemente liberando cálcio e fosfato para o meio. Os íons positivos de cálcio livres se ligarão aos íons negativos de fosfato do cimento para constituir a neutralidade elétrica. É formada uma camada intermediária de difusão/absorção de fosfatos de cálcio e alumínio e poliacrilatos na interface cimento/dente, a qual é firmemente presa à superfície dentária ${ }^{18}$.

A variação nos valores de adesão do CIV ao esmalte e à dentina humanos foi avaliada por POWIS et al. ${ }^{71}$ em 1982. Esta pesquisa mostrou que os condicionadores de superfície mais efetivos são aqueles de alto peso molecular. Condicionadores com baixo peso molecular que dissolvem o cálcio e alteram radicalmente a superfície do substrato são menos efetivos.

ABOUSH; JENKINS ${ }^{1}$ (1986) avaliaram a adesão de CIV restauradores ao esmalte e à dentina humanos após diversos tipos de tratamento. Foram avaliados: ChemFil/Dentsply, Fuji II/GC, Ketac Fil/ESPE e Aspa/Dentsply. Os 
autores concluíram que a limpeza com pedra pomes ou jato de bicarbonato da superfície que vai receber o material produz condições favoráveis à adesão.

JEMT; STALBLAD; OILO $^{46}$ (1986) avaliaram a resistência adesiva de 2 cimentos de policarboxilato e 2 CIV ao esmalte dentário humano em um estudo in vivo. Os CIV testados mostraram baixa adesão ao esmalte: $2,4 \mathrm{MPa}$ para o Ketac Cem/ESPE e 1,2 MPa para o Fuji I/GC. Em comparação aos resultados de outros trabalhos in vitro, estes foram muito baixos, o que indica que é mais difícil obter uma boa adesividade in vivo do que in vitro.

Os materiais utilizados para o ART mostraram adesão efetiva em um estudo por HOSOYA; GARCÍA-GODOY ${ }^{4}$ em 1998. Neste estudo foram realizadas restaurações, nas superfícies vestibulares de dentes extraídos, envolvendo dentina e esmalte. Os CIV utilizados foram o Ketac Molar Aplicap/ESPE e o Fuji IX GP/GC. Depois de realizadas as restaurações, os dentes foram seccionados e pela microscopia eletrônica de varredura não foram observadas fendas entre o material e a dentina e o material apresentava íntima adaptação com o esmalte.

A liberação de flúor dos cimentos de ionômero de vidro é um fator relatado por vários autores ${ }^{22,33,36}$.Os íons flúor são incorporados ao vidro durante a sua manufatura, para agir como desoxidante e para modificar a temperatura de fundição do vidro. Imediatamente após a mistura do pó de vidro com o ácido poliacrílico, esses íons flúor serão liberados da superfície das partículas de vidro. Mesmo depois da maturação do cimento (presa final), a matriz permanecerá porosa suficientemente para a movimentação livre de íons hidroxila $\left(\mathrm{OH}^{-}\right)$e flúor e, sendo as partículas de vidro também relativamente 
porosas, esses íons então poderão se movimentar constantemente dentro do corpo da restauração.

A liberação de flúor é considerável nos primeiros dias após a realização da restauração e/ou selamento diminuindo e se estabilizando com o passar do tempo. Por outro lado, se houver aplicação tópica de algum produto fluoretado os cimentos de ionômero de vidro têm a capacidade de reincorporar os íons flúor e voltar a liberá-lo de maneira semelhante àquela inicial. Dessa forma, este material pode ser considerado um verdadeiro reservatório de flúor intrabucal $^{36}$.

Com o objetivo de melhor compreender os novos materiais que continham flúor em suas formulações, FORSTEIN ${ }^{22}$ em 1990 avaliou a liberação de flúor de sete diferentes cimentos de ionômero de vidro restauradores, um cimento de ionômero de vidro para selamento, um amálgama e uma resina composta. Todos os materiais foram manipulados seguindo as orientações dos fabricantes. A medida da liberação de flúor foi realizada periodicamente e analisada por meio de um eletrodo previamente calibrado. Os resultados mostraram que o nível de flúor liberado pelos cimentos ionoméricos diminui com o tempo e um nível constante foi alcançado para a maioria dos produtos durante o período experimental. Quando o pH da solução de armazenagem foi abaixado para 5,0, houve um aumento na liberação do flúor. Nos cimentos de ionômero de vidro, a liberação de flúor foi significativamente maior que no amálgama e na resina composta.

HATIBOVIC-KOFMAN; KOCH ${ }^{36}$ propuseram-se, em 1991, a investigar in vivo e in vitro, a liberação de flúor de três marcas comerciais de cimento de ionômero de vidro, Vitrebond/3M, Ketac-Fil/ESPE e Chelon Fil/Dentsply. O 
estudo in vivo foi realizado por meio da leitura de flúor na saliva de escolares que haviam recebido restaurações destes materiais. O nível de flúor foi medido antes da colocação das restaurações, imediatamente após, depois de 3 semanas, 6 meses e 1 ano. A segunda parte do experimento foi realizada em laboratório, onde a liberação de flúor de espécimes foi medida semanalmente até a décima sexta semana. Na décima segunda semana, as amostras foram expostas a dentifrício fluoretado. A concentração de flúor na saliva, antes da colocação das restaurações, era de 0,04 ppm. Depois de três semanas de efetuadas as restaurações aumentou para 0,8 ppm e o nível permaneceu elevado, 0,3 ppm, mesmo decorrido 1 ano do início do experimento. No estudo in vitro, os cimentos de ionômero de vidro mostraram capacidade de absorver o flúor contido no dentifrício e liberá-lo para cavidade bucal.

A presença do flúor no meio bucal tem se mostrado um eficiente mecanismo de prevenção de cárie. Segundo SERRA; RODRIGUES ${ }^{75}$ em 1998, após comparação do efeito cariostático in vitro de diferentes materiais odontológicos, concluiu-se que os cimentos de ionômero de vidro convencionais e os modificados por resina apresentaram maior potencial cariostático quando comparados com os compômeros, que apresentaram pouco efeito cariostático, e com as resinas compostas ( $\left.R C^{\prime} s\right)$ com flúor que não o apresentaram. Esta propriedade cariostática dos CIV está diretamente ligada à liberação de flúor. De acordo com KIELBASSA; MULLER; GARCÍAGODOY $^{47}$ (1999), o efeito preventivo da liberação de flúor pelos materiais está relacionado com a diminuição da perda de minerais pelas estruturas adjacentes à restauração. 
Segundo CHRISTENSEN ${ }^{16}$, os CIV são os que mais liberam flúor para o meio bucal. Há RC's que possuem flúor em sua composição, entretanto não o liberam para o meio bucal. Esse autor ainda relata que os cimentos de alta viscosidade, ou seja, indicados para o ART, possuem liberação de flúor semelhante aos convencionais. Entretanto, alguns autores verificaram que os CIV de alta viscosidade às vezes possuem liberação de flúor inferior aos CIV convencionais $^{33}$, e que também existem diferenças na liberação entre os diferentes CIV de alta viscosidade.

Para avaliar a inibição de cárie nas margens de esmalte ao redor das restaurações de CIV desenvolvidos para o ART, SMALES; GAO ${ }^{79}$ (2000) realizaram um estudo in vitro comparando Fuji IX/GC, Ketac Molar/3M-ESPE e Compoglass/Vivadent. Os resultados sugerem que a liberação de flúor dos materiais restauradores confere algum grau de proteção ao esmalte adjacente contra a desmineralização in vitro.

Em uma revisão de literatura sobre a seleção de materiais restauradores para o ART, YIP et al. $^{94}$ (2001) salientam a importância de algumas características destes materiais: disponibilidade e custo, facilidade de uso, menor sensibilidade à técnica, condições de armazenamento e validade e material operatório requerido para sua aplicação. Segundo os autores ainda existe deficiência na resistência à fratura, na resistência ao desgaste, e na adesão para que a longevidade de restaurações de múltiplas superfícies e dos selamentos seja aumentada.

\section{3 - SELAMENTO DAS SUPERFÍCIES OCLUSAIS COM CIV}


As principais vantagens do cimento de ionômero de vidro comparado aos selantes resinosos convencionais são a liberação de flúor e sua menor sensibilidade quanto à contaminação com saliva ${ }^{58,70,89}$ durante sua aplicação. Os CIV aderem à estrutura dentária sem a necessidade da aplicação de ácidos, permitindo seu uso em dentes parcialmente irrompidos de difícil acesso ao isolamento absoluto ${ }^{18}$. Tais fatos têm motivado a realização de vários estudos utilizando o cimento de ionômero de vidro como material para o selamento oclusal há pelo menos três décadas.

Buscando aprimoramento do cimento de ionômero de vidro utilizado em 1972 por WILSON; KENT ${ }^{93}$, em 1974, McLEAN; WILSON ${ }^{57}$ realizaram um estudo clínico, testando a efetividade desse material na prevenção de cáries nas superfícies oclusais bem como sua adesão físico-química entre o cimento e o esmalte a longo prazo. O cimento utilizado foi o ASPA I/Dentsply. Duzentos e setenta e nove dentes posteriores de pacientes com idade entre 9 e 16 anos receberam o selamento, sendo que 250 foram avaliados após o primeiro ano através de inspeção clínica e exame radiográfico. Os dentes foram avaliados de acordo com o tamanho de suas fissuras e somente fissuras que possuíam largura igual ou superior a $100 \mu \mathrm{m}$ eram selecionadas para o estudo. Para os autores, fissuras estreitas dificultariam a inserção do material selador, não promovendo a penetração do mesmo no fundo das fissuras. Após a profilaxia, os dentes receberam isolamento relativo. A superfície do esmalte foi condicionada com ácido cítrico $50 \%$ por 30 segundos. O material foi manipulado em placa de vidro resfriada, depositado nas fissuras e pressionado firmemente nas mesmas com auxílio de um brunidor, tomando presa em torno de dois a quatro minutos após sua inserção. Excessos eram removidos e o 
material era protegido com um verniz após sua presa final. $\mathrm{O}$ índice de sucesso utilizando essa técnica foi considerado alto pelos autores, combinado com a manutenção da forma anatômica e da adaptação marginal. Após um ano, 84\% dos selamentos permaneceram intactos, e 78\% depois de dois anos. Somente em $10 \%$ dos casos houve perda completa do selamento após um ano e mais 4\% no período de dois anos. A incidência de cárie foi pequena e só ocorreu nos casos em que houve perda total do material.

Em 1976, WILLIANS; WINTER ${ }^{92}$, apresentaram os resultados da avaliação de 2 anos de um estudo clínico que comparou as propriedades de um CIV (Aspa II/Dentsply), de uma selante resinoso (Nuva Seal/L.D. Caulk) e de três outros materiais experimentais. $O$ índice de retenção foi de $21,1 \%$ para Aspa II, 44\% para Epoxylite 9075, 29,5\% para Espe 717, 20,3\% para Espe 71729 e $62 \%$ para Nuva Seal. A porcentagem de dentes cariados foi de $11,4 \%$ para Aspa II, 10\% para Epoxylite 9075, 14,1\% para Espe 717, 27,4\% para Espe 71729 e 8,4\% para Nuva Seal. Os autores concluíram que o CIV apresentou a mesma efetividade em prevenir cárie de fossas e fissuras do que o selante resinoso.

BOKSMAN et al. ${ }^{12}(1987)$ avaliaram a eficiência clínica de um selante resinoso e de um CIV. A amostra constou de 40 pacientes de 6 a 18 anos de idade, sendo que 122 dentes foram selados com Concise/3M e 125 com Fuji III/GC, sob isolamento absoluto. No controle de 6 meses $92,2 \%$ dos selantes de Concise/3M estavam totalmente retidos, $1,7 \%$ parcialmente retidos e $6,1 \%$ estavam ausentes. Quanto ao Fuji III/GC, 2\% estavam totalmente retidos, 4,3\% parcialmente retidos e $94 \%$ ausentes. Devido ao grande número de selantes de CIV estar ausente, o projeto foi abortado e estes dentes foram resselados com 
Concise/3M. Com base nos resultados os autores acreditaram que o uso do Fuji III para realização de selantes oclusais era arriscado.

McKENNA; GRUNDY55 (1987) realizaram pesquisa clínica para avaliar clinicamente o comportamento de selantes de CIV aplicados por THD's. Os operadores receberam aulas teóricas sobre as propriedades e correta manipulação do CIV e depois foram treinados em laboratório, onde selaram dentes extraídos. Foram selados 232 dentes de crianças de 6 a 11 anos. 0 material foi "assentado" na superfície com um condensador oval após profilaxia, lavagem, secagem e isolamento relativo dos dentes. Após 6 meses, 93\% dos selantes apresentavam retenção total e 4,5\% retenção parcial. Aos 12 meses, $82,5 \%$ apresentaram RT, 14\% RP e 3,5\% perda do selante. Apenas 1\% da amostra apresentou cárie.

Com o propósito de comparar os índices de retenção de selantes convencionais com os selamentos realizados com CIV, MEJÀRE; MJÖR ${ }^{59}$ (1990) selaram 208 dentes de 62 crianças com idade média de 9,2 anos, sendo que $47 \%$ delas tinham entre 7-8 anos. Foram selados 117 dentes com Delton/Johnson\&Johnson, 47 com Concise WS/3M e 44 dentes com Fuji III/GC. Estes dentes foram avaliados depois de 6 meses da aplicação e anualmente até os 5 anos, através de exame clínico e observação de réplicas ao microscópio óptico. Depois de 4,5-5 anos uma média de $90 \%$ dos selantes resinosos apresentavam retenção total. Clinicamente, $61 \%$ dos selantes com CIV estavam ausentes aos 6-12 meses e 84\% depois de 30-36 meses. Mas ao exame microscópico das réplicas em $95 \%$ dos dentes havia presença de material no fundo das fossas e fissuras após 36 meses. A presença de cárie foi 
encontrada em $5 \%$ dos dentes selados com os materiais convencionais e em nenhum dente selado com CIV após 4 anos.

TORPPA-SAARINEN; SEPPÄ ${ }^{87}$ (1990) estudaram clínica e microscopicamente a retenção de selantes de CIV. Foram selados 93 molares e pré-molares recém-irrompidos com Fuji III/GC sob isolamento relativo. Após 4 meses os índices de retenção foram os seguintes: $75 \%$ totalmente presentes, 22\% parcialmente e 3\% ausentes. Ao exame microscópico observou-se que em $80 \%$ dos fundos de fissura havia a presença de material.

Para avaliar a resistência de fissuras oclusais à desmineralização após a perda de selantes ionoméricos, SEPPÄ, FORSS ${ }^{74}$ (1991), realizaram um estudo in vitro. Os resultados mostraram que as fissuras seladas com CIV (Fuji III/GC) se tornaram mais resistentes a desmineralização do que aquelas não seladas. As autoras acreditaram que este resultado possa ter sido um efeito combinado do nível aumentado de flúor no esmalte e na placa dentária, e do material residual nas fissuras que permaneceu sem ser detectado clinicamente.

O trabalho proposto em 1994, por SUNDFELD et al. ${ }^{85}$, analisou por meio de avaliação clínica e microscópica, a técnica de selamento oclusal com materiais ionoméricos aplicados em esmalte dentário condicionado por ácido fosfórico a $37 \%$ durante 1 minuto. O estudo foi desenvolvido em 2 etapas. 0 trabalho clínico consistiu em selar sob isolamento absoluto, dentes posteriores permanentes, considerados hígidos clínico/radiograficamente. Os materiais ionoméricos empregados no estudo foram: Vitrabond, na proporção pó/líquido 1:1, Fuji II LC, e Variglass VLC, na proporção pó/líquido 1:2. Os mesmos foram aplicados na superfície oclusal dos dentes com uma sonda exploradora $n^{0} 5$. No estudo laboratorial, cortes de dentes humanos selados com os mesmos 
materiais foram analisados em microscópio óptico comum sob luz polarizada, para verificar a adaptação do material ionomérico às vertentes das cúspides. Decorridos 12 meses, os autores concluíram que os selamentos oclusais com materiais ionoméricos resinosos apresentaram excelente comportamento clínico, quanto à retenção na superfície oclusal. Concluíram também, que esses resultados são atribuídos à grande capacidade que esses materiais têm de penetrar abundantemente nos microporos do esmalte dentário condicionado por ácido fosfórico.

No estudo realizado em 1994 por KOMATSU et al. ${ }^{49}$, foi avaliada a retenção do selamento com Fuji III/GC, e o efeito preventivo de cárie desse selamento depois de realizadas reaplicações do mesmo. Os selamentos foram realizados em molares de noventa e uma crianças com média de idade de 6,6 anos. Inicialmente, os dentes foram limpos com pasta de pedra pomes/água e escova Robinson. Os dentes foram cuidadosamente isolados com roletes de algodão, já que não havia disponibilidade de sugador de saliva no local do atendimento. O selante foi manipulado seguindo as orientações do fabricante, e aplicado na superfície oclusal sem condicionamento ácido do esmalte. Após a presa do material, o selamento foi protegido com verniz. As crianças foram orientadas para não comer nos primeiros trinta minutos. O grupo controle para a avaliação da incidência de cárie foi obtido junto aos escolares que freqüentavam as escolas de primeiro e segundo graus, e o exame foi realizado anualmente. Depois de um ano, foram realizadas reaplicações do selante sempre que houvesse perda do material em algum sulco ou fissura. Analisando-se os resultados, observou-se que a taxa de retenção foi mantida com sucessivas reaplicações até o terceiro ano do estudo. A redução de cárie 
foi $76,1 \%$ no primeiro ano, $69,9 \%$ no segundo, e $66,5 \%$ até o terceiro ano. Para os autores, a reaplicação do selante é um método aceitável e simples, pois promove uma adequada retenção do material na superfície oclusal, além do que, permite ao esmalte adjacente ao selamento a incorporação do flúor disponível no material.

ARANDA; GARCÍA-GODOY ${ }^{6}$ (1995) publicaram os resultados de um estudo clínico que avaliou a retenção de um CIV modificado por resina desenvolvido para o selamento de fossas e fissuras (material experimental/GC). Um total de 25 pacientes de 7 a 14 anos de idade foram selecionados para o estudo. Os pacientes residiam em localidades sem fluoretação da água de abastecimento. Antes do selamento, foram realizadas tomadas fotográficas da superfície oclusal. Em seguida, os dentes receberam isolamento relativo, e logo após receberam o condicionador de dentina (GC America, Chicago, IL, USA) por 20 segundos. Os dentes foram lavados e secos suavemente para recebimento do CIV. Um explorador foi utilizado para aplicar o material nos sulcos e fissuras. O selante foi então polimerizado por 20 segundos , e em seguida protegido com um adesivo, para não se solubilizar em meio bucal. Após o término da técnica do selamento, foram realizadas moldagens da superfície oclusal e uma nova tomada fotográfica. Após 12 meses, somente $20 \%$ dos selantes estavam clinicamente presentes, $70 \%$ estavam parcialmente presentes e $10 \%$ ausentes. Não houve diferença na retenção dos selantes aplicados em dentes parcial ou totalmente irrompidos. Ao exame de réplicas no microscópio eletrônico de varredura, embora um considerável desgaste do cimento ionomérico tivesse ocorrido, ficava evidente 
sua presença no fundo das fissuras em todos os dentes examinados. Não houve o desenvolvimento de cárie em nenhum dente selado.

Para comparar a durabilidade clínica do selamento de fossas e fissuras com CIV e resina BIS-GMA, REUTERVING; van DIJKEN ${ }^{73}$ (1995) realizaram avaliação dos mesmos por um período de 3 anos. Os materiais testados foram Fuji III/GC e Delton/Johnson\&Johnson. A amostra foi composta de 47 pacientes com idade média de 7 anos, com 2 ou 4 molares hígidos erupcionados, totalizando 148 dentes selados. Para o selamento com Delton, os dentes foram limpos com profilaxia e atacados com ácido fosfórico a 37\% por 20 s. Para o selamento com o CIV os dentes também receberam profilaxia e depois ácido poliacrílico a $40 \%$ por 20s. A retenção após 36 meses foi de $79,2 \%$ para o Delton e 27,8\% para o Fuji III. Observou-se cárie em 4,2\% dos dentes selados com Delton e 1,4\% para os dentes selados com Fuji III.

Com o intuito de avaliar diferentes métodos para prevenir cárie de fissuras, SONGPAISAN et al. ${ }^{82}$ (1995) testaram, em crianças de 7-8 anos de idade, o efeito de 3 aplicações (no início do estudo, aos 6 e 12 meses) tópicas de flúor (ácido hidrofluorídrico 0,5\%) e do selamento oclusal com CIV (Fujill//GC) por dentistas e por professores treinados. Os resultados mostraram uma redução de cárie de 33\%, 52\% e 74\% respectivamente após 2 anos. Os autores acreditam que o efeito preventivo dos selamentos é devido ao período em que os selantes ficaram em posição, aos restos de material que podem permanecer no fundo das fossas e fissuras mesmo após a perda clínica dos selantes e ao flúor liberado pelo material.

Uma comparação das qualidades retentivas de 2 CIV usados como selantes oclusais foi realizada por WEERHEIJM; KREULEN; 
GRUYTHUYSEN $^{89}$ em 1996. Participaram da amostra 104 crianças com idade média de 10,4 anos. Foram utilizados Fuji III/GC (CIV desenvolvido para selamento) e Fuji IX/GC (CIV desenvolvido para ART) para a realização de 208 selantes (104 de cada material). Inicialmente os dentes foram limpos com pedra pomes e isolados com rolos de algodão. O Fuji IX foi aplicado nas fissuras com um brunidor e pressionado nas fissuras com o dedo, sendo a luva previamente vaselinada. Para o Fuji III, o material foi inserido nas fissuras com um instrumental Ash 49 e coberto com verniz, de acordo com as orientações do fabricante. Depois de 4 meses $45 \%$ do Fuji III e $72 \%$ do Fuji IX estavam totalmente presentes, aos 9 meses esta retenção caiu para 15\% e 52\% respectivamente. Após 9 meses todos os dentes se apresentaram livres de cárie. Concluiu-se que o material restaurador apresentou maior retenção do que aquele desenvolvido especialmente para o selamento.

Com objetivo de estudar a taxa de retenção dos cimentos de ionômero de vidro desenvolvidos para selamento, SMALES et al. ${ }^{78}$ (1996) realizaram um estudo clínico com 19 pacientes, perfazendo 62 dentes selados com selante resinoso Delton/Johnson\&Johnson (controle), e 69 selados com Fuji III LC/GC. Não se efetuou profilaxia no grupo que recebeu o CIV. Os dentes foram isolados com rolos de algodão, secos e condicionados com ácido poliacrílico a $10 \%$ por $15-20$ segundos. O material foi manipulado seguindo as orientações do fabricante numa proporção de 1/4:1. Em seguida, colocados na fissura com explorador e polimerizados por 40-60 segundos. Na seqüência, foram checadas a retenção e a oclusão. Os selamentos com Delton seguiram as orientações preconizadas pelo fabricante. Foram realizadas tomadas fotográficas dos selamentos no término da consulta bem como nas avaliações 
semestrais. Após 6 meses, os autores observaram que $74 \%$ dos selamentos realizados com cimento de ionômero de vidro necessitariam ser reaplicados, contra $11 \%$ dos selamentos com Delton. Uma lesão de cárie foi observada para cada material durante o estudo. Observaram também que o cimento ionomérico despende maior tempo de trabalho devido às dificuldades de manipulação do material.

Seguindo a mesma linha de investigação, RAADAL, UTKILEN, NILSEN ${ }^{72}$, em 1996, publicaram os resultados de um estudo clínico, em que os autores avaliaram a taxa de retenção e efeito preventivo da aplicação do cimento de ionômero de vidro reforçado por resina (Vitrabond/3M) em fossas e fissuras oclusais de primeiros e segundos molares permanentes, num período de 3 anos, comparando-os com a aplicação do selante resinoso (Concise/3M). Dezesseis crianças com idade entre 5 e 7 anos tiveram seus primeiros molares selados, e outras 37, com idade entre 11 e 13 anos, tiveram seus segundos molares selados. Antes da aplicação do selante, os dentes foram lavados com pasta de pedra pomes/água e taça de borracha, lavados e isolados com rolos de algodão. O Vitrabond, originalmente indicado para forramento, foi manipulado com uma porção de pó para uma gota de líquido e a mistura aplicada nas fissuras com uma sonda exploradora. Nenhum tipo de condicionamento do esmalte foi realizado. O material foi então polimerizado por 30 segundos. Para o selamento com o Concise, seguiram-se as recomendações do fabricante, sendo previamente a superfície do esmalte condicionada com ácido fosfórico $37 \%$ por 20 segundos. O selante foi levado à superfície oclusal e polimerizado por 30 segundos. As crianças foram avaliadas depois de 1, 6, 12, 24 e 36 meses, para checagem da retenção e cárie. Os 
resultados confirmaram que o selamento resinoso estava presente em todos os dentes depois de 2 anos. Após 3 anos, o material estava ausente em dois dentes e parcialmente presente também em dois dentes. Já o selamento com cimento ionomérico foi rapidamente perdido durante o estudo, com $6 \%$ de perda total no primeiro mês de avaliação e $91 \%$ depois de 3 anos. Com relação ao desenvolvimento de cárie, nenhuma lesão foi observada no selamento com Concise. Para o Vitrabond se detectou o aparecimento de 10 superfícies cariadas no decorrer do experimento. Diante do exposto, os autores concluíram que o selamento com selante resinoso é superior ao selamento com cimento ionomérico na prevenção da cárie dentária, e que a sua alta taxa de retenção é a responsável por essa comprovação.

Em 1996, SIMONSEN ${ }^{77}$, revisou os trabalhos clínicos, em que os autores avaliaram o cimento de ionômero de vidro reforçado com resina utilizado para o selamento de fossas e fissuras, e observou que, quando se avalia a taxa de retenção dos mesmos, os resultados não são encorajadores, pois os selantes resinosos exibem uma taxa de retenção muito superior aos do cimento ionomérico. Observou também que, os cimentos de ionômero de vidro restauradores apresentam um comportamento melhor que os cimentos ionoméricos seladores. Quando se avalia o potencial cariostático, os resultados são positivos, ou seja, o material tem capacidade de liberar e reincorporar flúor por longos períodos, o que o torna mais eficiente na prevenção de cárie nas superfícies oclusais, promovendo um endurecimento do esmalte adjacente ao material. Para o autor, os cimentos de ionômero de vidro reforçados por resina devem ser aprimorados e avaliados com pesquisas em longo prazo, para que sua indicação se torne rotineira na clínica odontopediátrica. 
VELASCO; NÖR; FIGUEIREDO ${ }^{88}$, em 1996, realizaram um estudo in vitro com o objetivo de analisar a penetração de um CIV convencional (Fuji IX - GC), e de um CIV reforçado com resina (Vitremer - 3M) nos sulcos e fissuras oclusais. Foram utilizados 24 pré-molares e 24 molares decíduos no estudo. Inicialmente, os dentes receberam profilaxia com aparelho de jato de bicarbonato de sódio, em seguida foram secos e condicionados com ácido fosfórico a $37 \%$ por 15 segundos. Depois de realizado o selamento, os dentes foram seccionados vestíbulo-lingualmente em três partes (mesial, médio, distal), com disco de diamante, preparando fatias de aproximadamente $200 \mu \mathrm{m}$ de espessura. Os cortes foram analisados em microscópio óptico com aumento de 40X. A análise estatística demonstrou que o cimento de ionômero de vidro Fuji IX penetrou mais profundamente nos sulcos e fissuras, em ambos dentes decíduos e permanentes (penetração total 97,22\% e 77,78\%) quando comparados com o cimento ionomérico Vitremer (penetração total $75 \%$ e $66,67 \%$ ). Os autores concluíram que os resultados obtidos pelo cimento ionomérico Fuji IX o beneficiariam nas taxas de retenção em trabalhos clínicos em longo prazo.

FORSS; HALME ${ }^{21}$, em 1998, compararam o grau de retenção e a eficácia na prevenção de cárie dos selamentos realizados com um cimento de ionômero de vidro (Fuji III/GC), e de um selante resinoso (Delton/Johnson\&Johnson), decorridos 7 anos do procedimento selador. Cento e sessenta e seis crianças tiveram seus primeiros e segundos molares permanentes selados logo após a erupção. A avaliação de dois anos mostrou uma baixa taxa de retenção para o selamento com cimento de ionômero de vidro, mas nenhuma diferença em relação ao aparecimento de cárie entre os 
grupos. Após 7 anos de acompanhamento das superfícies oclusais seladas, $10 \%$ dos cimentos de ionômero de vidro e $45 \%$ dos selantes resinosos estavam totalmente retidos e parcialmente retidos em $9 \%$ e $20 \%$. Vinte e três $(23,5 \%)$ das superfícies seladas com cimento de ionômero de vidro e 16 $(16,5 \%)$ das seladas com selante resinoso, estavam cariadas ou restauradas.

SMALES; WONG ${ }^{81}$ (1999), publicaram um estudo que comparou a performance clínica após dois anos da aplicação de um selante ionomérico modificado por resina (Fuji III/GC) e um selante resinoso (Delton Opaque/Johnson\&Johnson). Quarenta e sete selantes com Fuji III e 41 com Delton foram avaliados. Dos selantes com Fuji III, 62\% apresentaram retenção parcial e $38 \%$ perda total. Dos selantes com Delton, 32\% apresentaram retenção total, 58\% retenção parcial e 10\% perda total. Foi observada presença de cárie em $7,3 \%$ dos dentes selados com Delton e 2,1\% dos dentes selados com Fuji III.Os autores concluíram que a baixa retenção do material ionomérico implica em cuidados com o uso deste material em aplicações únicas.

Avaliar a retenção e a prevenção de cárie de selantes oclusais realizados com CIV convencional (Ketac-Bond/ESPE) e modificado por resina (Vitremer/3M) foi o objetivo do estudo realizado por PEREIRA et al. ${ }^{64}$ em 1999. Participaram da amostra 200 crianças de 6-8 anos com primeiros molares hígidos e não selados, 200 dentes foram selados com Vitremer, 200 com Ketac-Bond e 432 dentes serviram como controle. A superfície oclusal dos dentes foi limpa com pasta de pedra pomes e água e, logo após, recebeu isolamento relativo e condicionamento com ácido fosfórico $35 \%$ por 30 s. A aplicação dos materiais seguiu as orientações do fabricante, sendo que a proporção pó/líquido do Vitremer foi de 1:2, para se conseguir um material com 
mais fluidez. Foi aplicado o primer do próprio produto antes da inserção do Vitremer. A aplicação dos dois materiais foi realizada com sonda exploradora $n^{\circ}$ 5. Os índices de retenção total do Vitremer foram 59\% e 36\% aos 6 e 12 meses respectivamente e do Ketac-Bond de 24\% aos 6 meses e $15 \%$ aos 12 meses. Não houve desenvolvimento de lesão de cárie em nenhum dente selado. Os dentes controle apresentaram 16\% e 23\% de incidência de cárie aos 6 e 12 meses respectivamente. Os autores concluíram que o uso de CIV para o selamento de superfícies oclusais é um método eficaz na prevenção de cárie.

No mesmo ano de 1999, MACHADO et al. ${ }^{53}$, avaliaram por meio de pesquisa clínica a retenção de um cimento de ionômero de vidro modificado por resina (Vitremer/3M), aplicado como selante de fossas e fissuras, depois da realização de diferentes pré-tratamentos do esmalte oclusal. Participaram do estudo 60 crianças, com idade entre 6 a 10 anos, num total de 220 primeiros molares permanentes, divididos aleatoriamente em quatro grupos como se seguem:- grupo I- condicionamento do esmalte com ácido fosfórico 37\%; IIácido maleico a 10\%; III- Primer do produto; IV- sem condicionamento. Inicialmente, os dentes receberam profilaxia com aparelho de jato de bicarbonato de sódio, recebendo em seguida isolamento relativo e o prétratamento do esmalte nas regiões de fossas e fissuras, para aplicação do cimento de ionômero de vidro. Durante o proporcionamento do material, para se conseguir uma mistura mais fluida, a proporção pó/líquido do material foi alterada para $1 / 4$ da medida de pó e uma gota de líquido. $O$ material foi levado à superfície das fissuras com auxílio de uma sonda, cuidadosamente adaptada aos sulcos e fissuras e, em seguida, polimerizado por 40 segundos. As 
avaliações quanto ao grau de retenção foram realizadas depois de 5 e 12 meses, totalizando-se 190 e 181 dentes analisados, respectivamente. A análise estatística demonstrou que os grupos I e II apresentaram os maiores índices de retenção total, sem diferença entre ambos, sendo que existiu uma diminuição no índice de retenção total depois de decorridos 12 meses em todos os grupos. O grupo III apresentou o menor índice de retenção total e o maior índice de perda do material. Os autores concluíram o estudo apontando que a utilização dos ácidos previamente à aplicação do cimento de ionômero de vidro como selante, favorece a sua retenção nas fossas e fissuras.

POULSEN; BEIRUTI; SADAT ${ }^{70}$ (2001) compararam a retenção e o efeito sobre a cárie de selantes realizados com CIV e com material resinoso. Os materiais testados foram Delton/Johnson\&Johnson e Fuji III/GC. Na avaliação de 3 anos os índices de retenção encontrados foram os seguintes: Retenção total 3,4\% Fuji III e 74,1\% Delton, Perda total: 89,3\% Fuji III e 9,8\% Delton. Os dentes selados com Fuji III apresentaram 3,38 vezes mais chance de desenvolver cárie do que os selados com Delton Os autores concluíram que os selantes realizados com Fuji III apresentaram menor proteção do que aqueles realizados com Delton.

LUCA-FRAGA; PIMENTA ${ }^{52}$ (2001) avaliaram clinicamente materiais híbridos utilizados para o selamento oclusal. A amostra foi composta por 100 crianças de 7 a 8 anos que receberam selantes nos dentes 36 e 46 com Vitremer/3M na proporção de 1:2 e Dyract/Dentsply (após condicionamento com ácido fosfórico 35\% por 30s) e outras 66 crianças que participaram do grupo controle. Após 12 meses 95,9\% e 85,7\% do Dyract e do Vitremer, respectivamente, apresentaram retenção total. Quanto ao desenvolvimento de 
cárie, $13,8 \%$ do grupo controle e $1 \%$ do grupo experimental desenvolveram a lesão. Os autores concluíram que este tipo de material (híbridos) apresentou altos índices de retenção e foi capaz de prevenir a cárie, sendo portanto indicado seu uso para selamento de fossas e fissuras, agindo como barreira física associada ao efeito anticariogênico do material.

Em 2003, PEREIRA et al. ${ }^{63}$ publicaram os resultados de avaliação de 3 anos de selantes realizados com CIV convencional (Ketac-Bond/ESPE) e modificado por resina (VItremer/3M). Os índices de retenção do Vitremer foram: $13 \%$ retenção total, $21 \%$ retenção parcial e $66 \%$ de perda total. Para o KetacBond foram: $4 \%$ de retenção total, $9 \%$ de retenção parcial e $87 \%$ de perda total. O grupo experimental apresentou 56\% menos incidência de cárie do que o grupo controle. Os autores concluíram que apesar dos índices de retenção serem baixos, os materiais ionoméricos mostraram um efeito cariostático em relação ao grupo controle.

\section{4 - SELAMENTO DAS SUPERFÍCIES OCLUSAIS COM CIV NO CONTEXTO DO ART}

Além de ser usado como material restaurador, o CIV também pode ser utilizado como selante oclusal. Na filosofia do ART o mesmo CIV é utilizado tanto para restaurações quanto para selamentos oclusais ${ }^{25}$.

Tendo em vista que a extração dentária na maioria das vezes ainda é a única opção de tratamento odontológico para residentes de áreas rurais e suburbanas em países em desenvolvimento, FRENCKEN et al. ${ }^{23}$ (1994) desenvolveram em uma população rural da Tailândia um trabalho baseado no ART. Foram realizadas 529 restaurações e 148 selamentos em dentes 
decíduos e permanentes de 277 crianças. $O$ material utilizado foi 0 ChemFil/Dentisply. Após 1 ano verificou-se um índice de retenção dos selamentos de $73 \%$ nos dentes decíduos e de $78 \%$ nos dentes permanentes. As crianças ficaram felizes em receber tratamento dentário através desta técnica e mostraram pouco medo. Os autores concluíram que a técnica do ART é um procedimento promissor nos tratamentos da cárie para uso em áreas rurais e sub-urbanas de países em desenvolvimento.

Frente ao pequeno acesso da população do Zimbábue ao tratamento odontológico, FRENCKEN; MAKONI; SITHOLE ${ }^{29}$, 1996; introduziram um programa de saúde bucal baseado no Tratamento Restaurador Atraumático (ART). As bases do programa consistiam em educação, prevenção e tratamento restaurador. A idade média dos pacientes era de 13,9 anos e o CPOD de 1,1 , sendo que $94 \%$ do índice total era representado pelo componente "cariado" e $81 \%$ das cáries acometia a superfície oclusal dos dentes. Um cimento de ionômero de vidro foi utilizado como material restaurador e também em selamentos oclusais. Foram seladas 511 superfícies oclusais com ChemFil Superior (Dentisply) através da técnica da pressão digital por 2 dentistas e 2 THD’s. O tempo médio para aplicação dos selantes foi de 9,4 min. Após 1 ano foram avaliados 365 selantes $(70,4 \%)$ e a porcentagem de selantes retidos foi de $73,7 \%$, sendo que $60,3 \%$ apresentaram retenção total e 13,4\% retenção parcial e 99\% dos dentes selados se mostraram livres de cárie. A satisfação com a modalidade de tratamento do ART foi mostrada por $95 \%$ dos estudantes. A retenção dos selamentos foi influenciada pelo operador, sendo que aqueles realizados pelos CD’s tiveram maior índice de retenção. 
Concluiu-se que o ART pode ser parte da resposta à falta de acesso ao tratamento odontológico que afeta milhares de pessoas.

SMALES; GAO; HO HO $^{80}$ (1997) realizaram uma avaliação in vitro de selamentos oclusais com os novos materiais desenvolvidos para o ART. Foram testados Fuji IX/GC, Fuji IX GP/GC, Fuji IX GP encapsulado/GC, Ketac Molar/ESPE e Delton/Johnson\&Johnson como controle. Trinta molares humanos extraídos foram divididos aleatoriamente em 5 grupos e receberam os selamentos com CIV através da técnica do $\mathrm{ART}^{25}$. Os dentes que receberiam selamento com CIV foram condicionados com ácido poliacrílico a $10 \%$ por 15 segundos. A seqüência para a aplicação do Delton seguiu as orientações do fabricante. Os resultados mostraram haver diferença estatisticamente significante entre os materiais no que diz respeito a microinfiltração marginal de corantes, que foi maior para os materiais ionoméricos. Com relação à penetração dos materiais nas fissuras, os selamentos de CIV (através da técnica de pressão digital) tiveram um melhor resultado do que o resinoso aplicado passivamente.

FRENCKEN; MAKONI; SITHOLE ${ }^{30}$, 1998; relataram os resultados da avaliação de 3 anos de um programa de Saúde Bucal baseado no ART realizado entre estudantes no Zimbábue. Os pacientes da pesquisa tinham em média 14,1 anos de idade, sendo que só os pacientes com alto risco à cárie $(C P O D \geq 3,0)$ e dentes com fissuras profundas receberam selamentos. Foram realizados 95 selamentos em 66 estudantes com o cimento de ionômero de vidro restaurador Fuji IX/GC, através da técnica da pressão digital. O tempo médio para realização dos selamentos foi de 10,7 minutos. Depois de 3 anos, a perda de amostragem foi de 30,5\%. A avaliação foi realizada conjuntamente 
por 2 examinadores independentes. Os índices de retenção (parcial e total sem a presença de cárie) foram de $89,8 \%$ no primeiro ano, $85,9 \%$ no segundo e $71,4 \%$ após 3 anos, sendo que 96,3\% dos dentes selados permaneceram livres de cárie durante os 3 anos do estudo. Os autores concluíram que o programa proporcionou alta qualidade em prevenção na população estudada.

FRENCKEN et al. ${ }^{26} 1998$ avaliaram restaurações e selamentos realizados em 569 estudantes do Zimbábue, com idade média de 13,9 anos, através do ART. Foram realizados 511 selantes em $1^{\text {os }}$ e $2^{\text {os }}$ molares permanentes com ChemFil Superior/Dentisply por 2 CD's e 2 THD's, através da técnica da pressão digital. O tempo médio gasto para a aplicação dos selantes foi de 9,3 minutos. Dentes de pacientes que não tiveram o consentimento para a realização do tratamento foram considerados como controle. Após 3 anos foram avaliados 314 selamentos com perda de $38,6 \%$ da amostra sendo que $20,4 \%$ estavam completamente retidos e $26,1 \%$ parcialmente retidos. Não houve diferença estatisticamente significante na retenção entre primeiros e segundos molares. Os autores relatam que a maioria dos selamentos foi perdida durante o primeiro ano após sua aplicação e $91,6 \%$ das superfícies seladas permaneceram por 3 anos sem desenvolverem cárie. As superfícies seladas tiveram 4 vezes menos chance de desenvolver cárie quando comparadas às superfícies não seladas. Concluiu-se que o ART promoveu tratamento dental preventivo e curativo satisfatório aos pacientes estudados.

Com o objetivo de avaliar a sobrevivência de selantes-ART após 3 anos, PHANTUMVANIT et al. ${ }^{67}$ realizaram um estudo em vilas rurais da Tailândia. Foram selados 104 molares permanentes com cárie de esmalte com um CIV restaurador (ChemFil/Dentsply) usando a técnica do ART. No controle de 3 
anos, 33\% da amostra foi perdida. O índice de sobrevivência dos selamentos foi de $85-69 \%$, 73-54\% e 60-40\% em 1, 2 e 3 anos respectivamente. Apesar do baixo índice de sobrevivência, mas considerando sua simplicidade e facilidade de realizar, o selante-ART, segundo os autores, é prático e apresenta um bom custo-benefício como opção para o selamento oclusal em programas públicos.

Em um estudo clínico, HO, SMALES, FANG ${ }^{38}$ (1999) avaliaram a performance de 2 cimentos de ionômero de vidro usados no Tratamento Restaurador Atraumático: Fuji IX/GC e ChemFil Superior/Dentisply. Participaram do projeto 23 adultos saudáveis com pequenas cavidades oclusais. Foram realizadas restaurações e selamentos com os dois materiais em cada paciente. Após 2 anos, ao exame clínico, 34,5\% dos selamentos pareciam estar completamente ausentes, 63,2\% parcialmente presentes. Não houve diferença estatisticamente significante entre os dois materiais estudados. Foi observada a presença de cárie em 5,3\% das fissuras expostas, mas os autores acreditam que muitas destas lesões podiam estar presentes no início do estudo mas não puderam ser detectadas clinicamente.

Em uma revisão da literatura sobre ART, FRENCKEN; HOLMGREN ${ }^{28}$ (1999) pesquisaram a efetividade do tratamento em prevenir cárie. Com relação aos selamentos com CIV foi mostrado que apesar de os índices de retenção serem menores do que os índices dos selantes resinosos, o desenvolvimento de cárie em superfícies seladas ocorreu em 4-8\% após 3 anos. Se comparadas com superfícies não seladas, estas apresentam 4 vezes mais chances de desenvolver cárie em dentina do que as superfícies seladas, após 3 anos. 
Com o objetivo de verificar a real possibilidade de realização do Tratamento Restaurador Atraumático e verificar seu comportamento clínico, HOLMEGREN et al. ${ }^{41}$, 2000; conduziram um estudo na China em pacientes de 12-13 anos com CPOD de 0,6. Foram realizados procedimentos restauradores e preventivos. O material utilizado foi o cimento de ionômero de vidro de alta viscosidade Ketac Molar (3M-ESPE). O selamento de fossas e fissuras foi indicado apenas para dentes com presença de mancha branca e para aqueles com sulcos profundos, totalizando 191 dentes selados, por apenas 1 operador, através da técnica da pressão digital. A avaliação foi feita por um examinador independente, que avaliou 93\% da amostra após 36 meses. O índice de retenção dos selantes (parcial+total) foi de $72 \%$ e $98 \%$ das superfícies seladas encontravam-se livres de cárie, após 3 anos. Os autores concluíram que o uso do ART tanto para restaurar quanto para prevenir as cáries (através dos selamentos) se mostrou apropriado, efetivo e aceitável.

MOTSEI; KROON; HOLTSHOUSEN ${ }^{61}$ em 2001, realizaram um estudo em que restaurações e selamentos foram realizados em dentes decíduos e permanentes através da técnica do tratamento restaurador atraumático. $O$ material das restaurações foi o Fuji IX/GC e dos selantes o Fuji III/GC. O tratamento foi realizado e avaliado pela mesma THD. As avaliações foram realizadas nas salas de aula sob luz natural depois de 6 e 12 meses e foram consideradas as propriedades retentivas e preventivas. A retenção dos selamentos nos dentes permanentes foi de $10,4 \%$ aos 12 meses, sendo que 98,9\% dos dentes que receberam o selante permaneceram livres de cárie. Os autores atribuíram os baixos valores de retenção alcançados ao material 
utilizado, a falta de treinamento prévio, a motivação e habilidade do operador, a anatomia oclusal e ao estágio de erupção dos dentes.

YIP; SMALES ${ }^{95}$ publicaram em 2002 uma revisão de literatura sobre os CIV usados como selantes através do ART. A média da retenção encontrada para os mesmos após 3 anos é de $70 \%$ (parcial e total), com desenvolvimento de cárie variando entre 0 e 4\%. Os autores afirmam que o uso destes selantes reduz a cárie em fissura quando comparado a dentes não selados, mas que sua retenção relativamente baixa pode implicar em um tempo reduzido de prevenção, que ainda não foi estipulado. Os autores sugerem o desenvolvimento de estudos em populações com alto risco a cárie por um maior período de tempo.

GAO et al. ${ }^{32} 2003$ compararam a performance de 2 CIV desenvolvidos para a técnica ART utilizados em restaurações e selamentos de pacientes adultos. Foram executados 105 selamentos (56 com Fuji IX/GC e 49 com Ketac Molar/3M-ESPE) através da técnica descrita para o ART (pressão digital) por 3 operadores. Tanto no baseline quanto nas avaliações foram tiradas fotos para comparações. Após 30 meses, avaliou-se apenas 24,5\% da amostra inicial, sendo que $89,7 \%$ dos selantes estavam parcialmente retidos e não houve desenvolvimento de cárie em nenhum dente selado. Os 2 materiais testados não apresentaram diferença estatisticamente significante.

TAIFOUR et al. ${ }^{86}$ (2003) estudaram os efeitos de selamentos com CIV em primeiros molares recém-erupcionados. Participaram da amostra 60 crianças $($ ceod $=4,4)$ de 6 a 7 anos, sendo que cada uma delas tinha pelo menos um primeiro molar não erupcionado e outro recém-erupcionado com a face oclusal visível e livre de tecido gengival. Foram aplicados 101 selantes através da 
técnica do $\mathrm{ART}^{25}$ utilizando-se Fuji IX/GC por 8 dentistas. Os dentes eram isolados com rolinhos de algodão, limpos com sonda e condicionados com ácido poliacrílico por 10 a 15 segundos. O material era manipulado segundo orientações do fabricante e aplicado na superfície oclusal através da técnica da pressão digital. Os dentes não erupcionados foram incluídos no grupo controle. Após 5 anos, $10,3 \%$ dos selamentos estavam total ou parcialmente retidos. Comparando-se os grupos, observou-se que depois de 5 anos a probabilidade de desenvolvimento de lesões de dentina nos molares não selados foi de 2,1 vezes maior do que nos dentes selados. Os autores concluíram que o selamento de molares recém erupcionados com CIV de alta viscosidade pode ser uma medida preventiva em crianças com alto risco à cárie. 


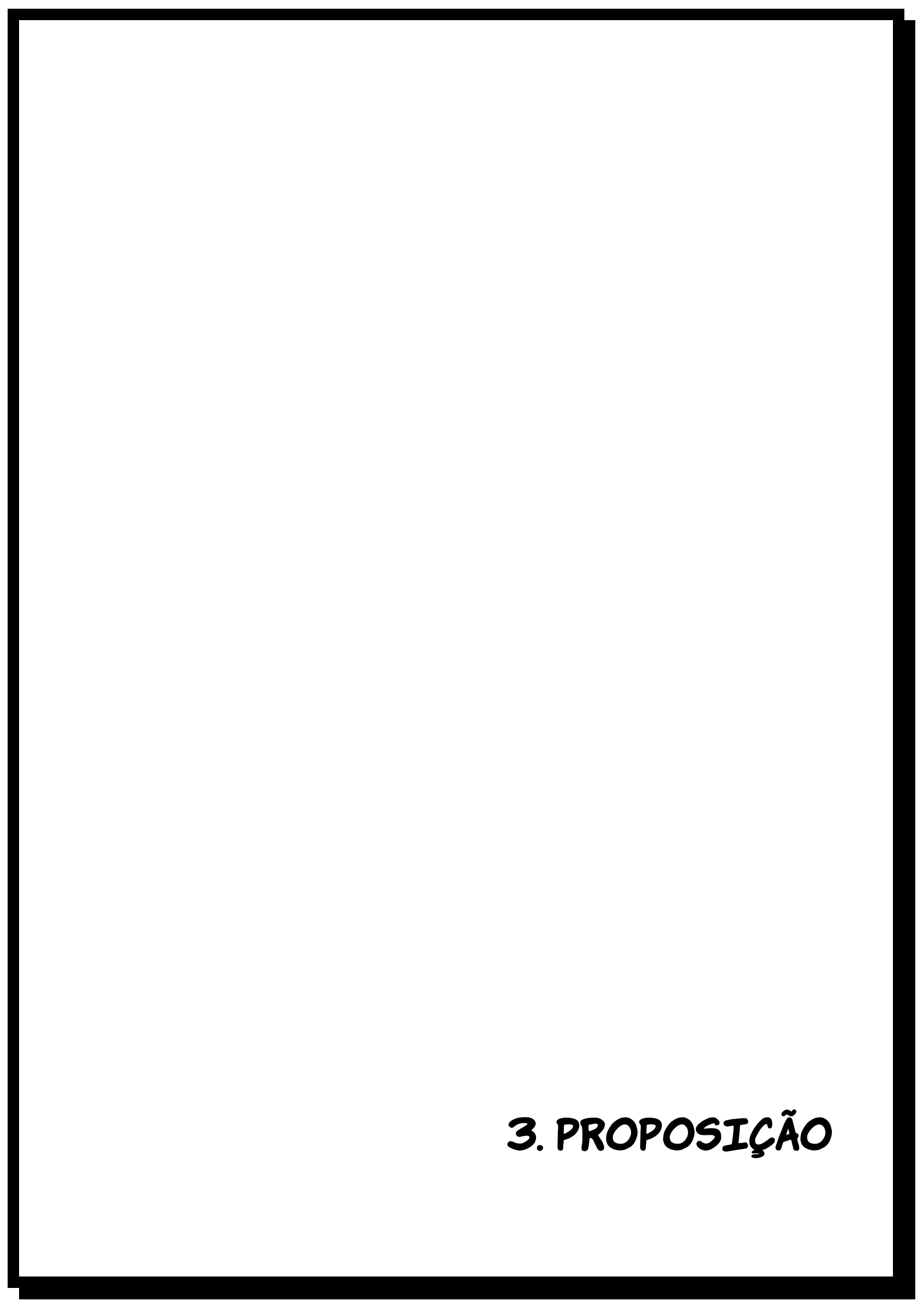




\section{PROPOSIÇÃO}

Este estudo se propôs a avaliar por períodos de 12 e 36 meses o desempenho clínico de selamentos de fossas e fissuras realizados pela técnica do ART em uma população com alto índice de cárie. Foram testados dois materiais: um cimento de ionômero de vidro de alta viscosidade (ChemFlex/Dentisplay) e outro convencional (Vidrion R/SS White).

As hipóteses nulas são:

HIPÓTESE 1: Não existe diferença na retenção dos dois materiais testados.

HIPÓTESE 2: Não existe diferença na porcentagem de dentes livres de cárie nos dentes selados com os dois materiais testados. 


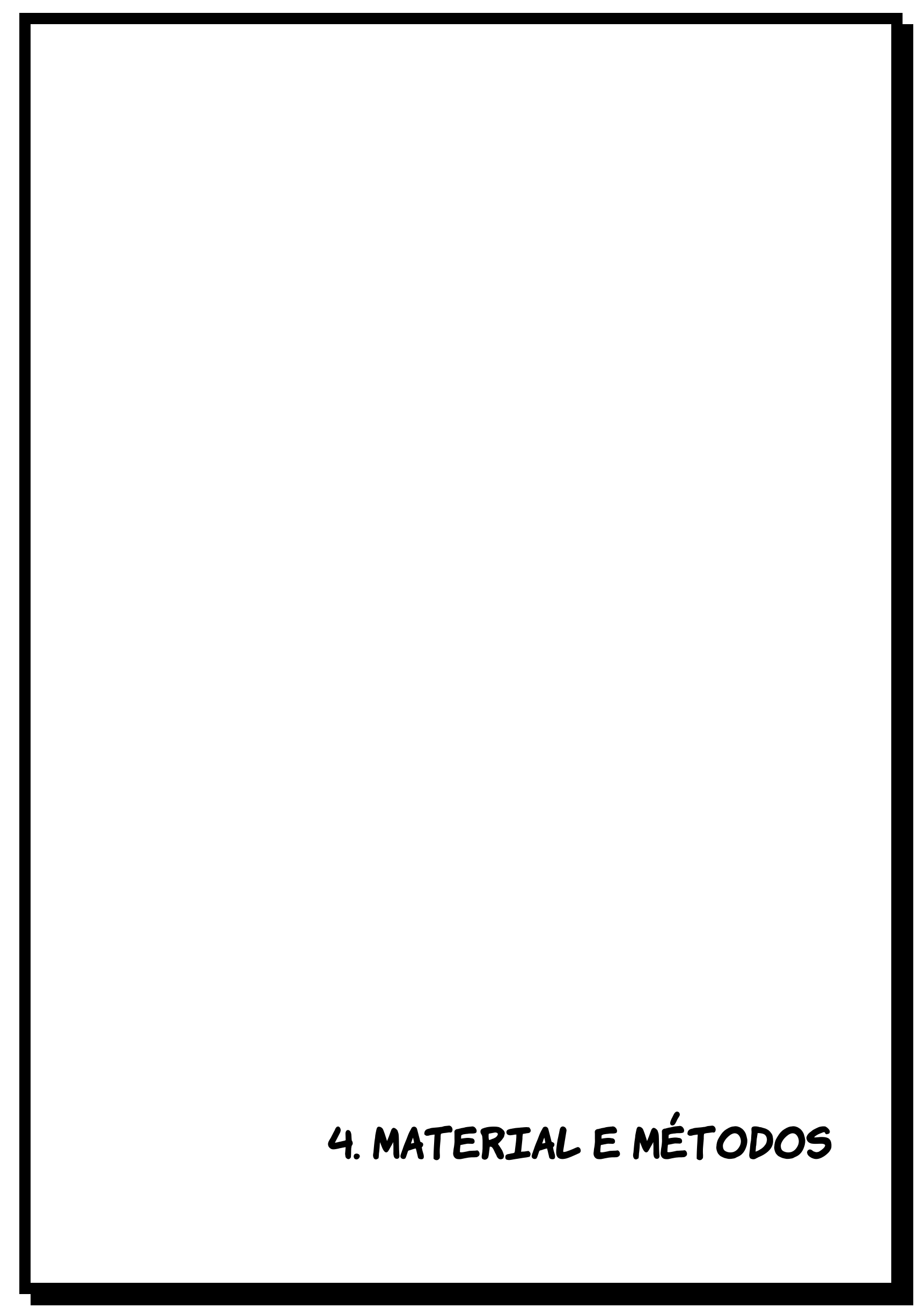




\section{MATERIAL E MÉTODOS}

\section{1-MATERIAIS TESTADOS}

\begin{tabular}{|c|c|c|c|c|}
\hline \multicolumn{2}{|c|}{ Material } & Fabricante & $\begin{array}{c}\text { Lote de } \\
\text { fabricação }\end{array}$ & Características \\
\hline 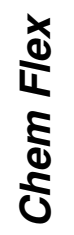 & $\begin{array}{c}\text { Pó } \\
\text { Líquido }\end{array}$ & $\begin{array}{c}\text { Dentsply Detrey } \mathrm{GmbH}, \\
\text { Alemanha }\end{array}$ & $\begin{array}{l}9805000284 \\
9804001577\end{array}$ & $\begin{array}{l}\text { CIV restaurador de } \\
\text { alta viscosidade }\end{array}$ \\
\hline$\frac{\alpha}{2}$ & $\begin{array}{c}\text { Pó } \\
\text { Líquido }\end{array}$ & $\begin{array}{l}\text { SS White, RJ, } \\
\text { Brasil }\end{array}$ & & $\begin{array}{l}\text { CIV restaurador } \\
\text { convencional }\end{array}$ \\
\hline
\end{tabular}

\section{2 -DELINEAMENTO DO ESTUDO}

Antes de o estudo ser iniciado foi obtida a aprovação do mesmo pelo Comitê de Ética local (Anexo 1). Para que os pacientes fossem incluídos na amostra foi necessária a autorização dos pais e/ou responsáveis através da assinatura do documento de consentimento livre e esclarecido (Anexos 2 e 3) (Elaborado com base na resolução 196/96 do conselho Nacional de Saúde do Ministério da Saúde, publicada no Diário Oficial, no dia 09/10/1996, Brasília).

Foram selecionados 42 crianças com idades entre 6 e 8 anos estudantes da Escola Municipal Ayrton Bush da cidade de Bauru.

Os critérios para seleção e inclusão dos voluntários foram os seguintes: possuir pelo menos 2 primeiros molares permanentes recém-irrompidos com ausência clínica de cavitação e ceod entre 2 e 5. 


\section{2 -FASE EXPERIMENTAL}

O primeiro procedimento realizado com os pacientes foi o preenchimento de uma ficha (Anexo 4) com os dados pessoais do paciente, história dental pregressa e necessidade de tratamento.

Durante este exame inicial também foram avaliados o índice de placa visível (IPV) e o índice de sangramento gengival (ISG), segundo AINAMO; BAY, $1975^{3}$. Os dentes foram avaliados na porção cervical da coroa, nas faces vestibular e lingual. Na face vestibular, dois pontos foram avaliados, na mesial e central enquanto que na lingual somente a porção central foi avaliada. No caso de existência de placa visível, o escore 1 foi anotado, enquanto que o escore 0 foi anotado quando da não observância de placa visível. Caso o dente em questão não estivesse presente na boca, ou fosse impossível de se avaliar, o escore 9 foi anotado. Os escores são os mesmos para o índice de sangramento gengival, sendo escore 1 (positivo) se houver sangramento até 10 segundos após a sondagem com sonda periodontal e escore 0 (negativo) se o sangramento cessasse rapidamente ou não existisse.

Para o IPV, foram avaliados todos os dentes dos hemi-arcos direitos e para o ISG foram avaliados os primeiros molares e os incisivos centrais permanentes, sendo os do lado direito para o arco superior e os do lado esquerdo para o arco inferior. Este método de verificação de placa e de sangramento gengival foi escolhido pela simplicidade de realização e principalmente pela facilidade de esclarecer ao paciente quanto ao estado atual da sua saúde bucal, assim como incentivá-lo para a melhoria da mesma. 
Todo o tratamento odontológico requerido pelos voluntários foi executado pela equipe responsável pelo projeto. Todos os procedimentos clínicos (selamento) foram realizados por um único operador para padronização da técnica, a fim de minimizar variações. Em cada criança foram realizados pelo menos um selante de cada material testado sendo que ao todo foram realizados 150 selantes, 74 com ChemFlex e 76 com Vidrion R. A distribuição dos materiais se deu de maneira alternada e seqüencial e estes dados anotados em ficha específica (Anexo 5).

\subsection{1 - Descrição da seqüência clínica realizada}

Para a realização da técnica, os pacientes foram posicionados sobre uma mesa com um encosto acolchoado para cabeça preso na sua extremidade, proporcionando relativo conforto e um posicionamento adequado com relação ao operador ${ }^{24}$ (Figura 1). Não foram empregados equipamentos odontológicos convencionais tais como: mocho, cadeira odontológica, compressor e instrumentos rotatórios. Foram utilizados instrumentais esterilizados. Uma luz auxiliar portátil foi utilizada para melhorar a visualização em todas as etapas do tratamento (Figura 2).

Os procedimentos clínicos utilizados para a execução dos selantes descritos a seguir são os mesmos descritos no Manual sobre $\mathrm{ART}^{25}$ publicado pela OMS. Antes da realização dos selamentos as crianças realizaram higiene bucal com escova e creme dental.

- Isolamento do campo operatório, feito com rolos de algodão, somente na região a ser tratada, para que se trabalhe em um meio livre de umidade. $\mathrm{Na}$ Figura 3 pode-se visualizar o aspecto inicial do dente a ser selado; 
- Remoção de restos alimentares e placa bacteriana da superfície oclusal com sonda exploradora $n^{\circ} 5$ (Duflex, SS White) (Figura 4);

- Limpeza da superfície a ser selada com o uso de bolinhas de algodão molhadas em água, removendo resíduos (Figura 5);

- Condicionamento da superfície através da aplicação de bolinha de algodão saturada com solução ácida (Ácido poliacrílico 40\%). A bolinha é friccionada na superfície oclusal por 10 a 15 segundos (Figura 6);

- Lavagem da superfície repetidas vezes com algodão molhado (Figura 7);

- Secagem da superfície com bolinhas de algodão (Figura 8);

- Manipulação do material seguindo as recomendações do fabricante, na proporção de 1:1;

- Aplicação do material sobre as fossas e fissuras com ligeiro excesso através do uso de uma sonda exploradora

- Pressão digital: após a inserção do material na cavidade, com o dedo polegar enluvado e vaselinado, faz-se pressão sobre o material por 1 minuto. Esta pressão auxilia na remoção de excessos e melhora a adaptação do selante (Figura 9).

- Remoção de excessos

- Checagem da oclusão com o auxílio de um papel de articulação. A oclusão é checada e o material é desgastado com esculpidores, se necessário (Figuras 10 e 11).

- Remoção de excessos de vaselina com o auxílio de uma gaze. 
- Aplicação de agente protetor superficial: um protetor de superfície (esmalte de unha incolor) é aplicado para proteção do material contra sinérese e embebição (Figura 12).

O paciente foi instruído a não ingerir alimentos ou líquidos por, no mínimo, 1 hora.

Fotografias foram tiradas após a limpeza dos dentes (inicial) e ao final da realização do procedimento (baseline) para futuros esclarecimentos, se necessário. 


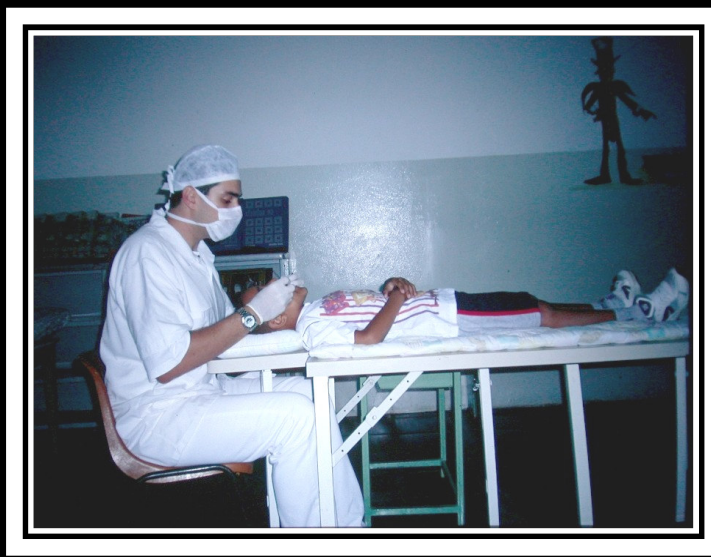

Figura 1: Posicionamento do paciente e do operador

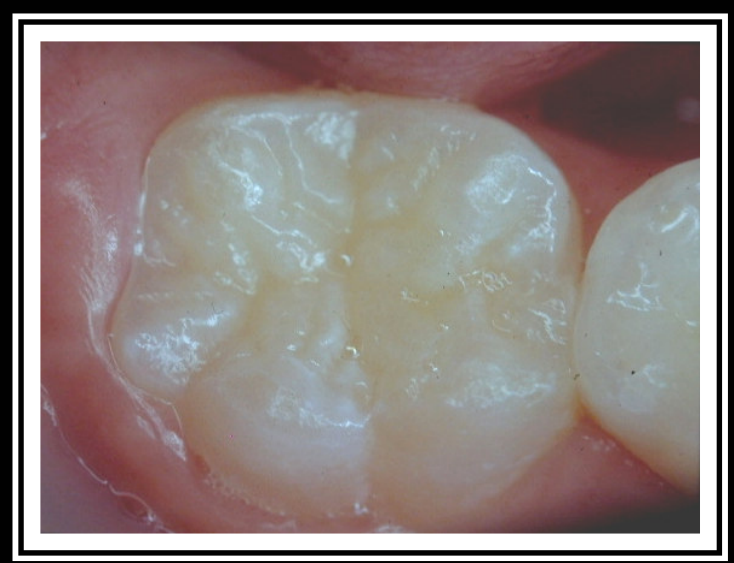

Figura 3: Aspecto inicial do dente a ser selado

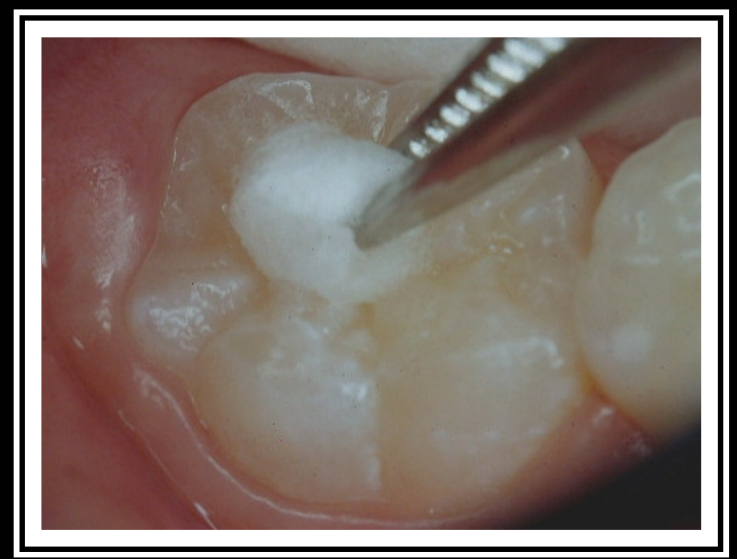

Figura 5: Limpeza da superfície a ser selada com bolinha de algodão

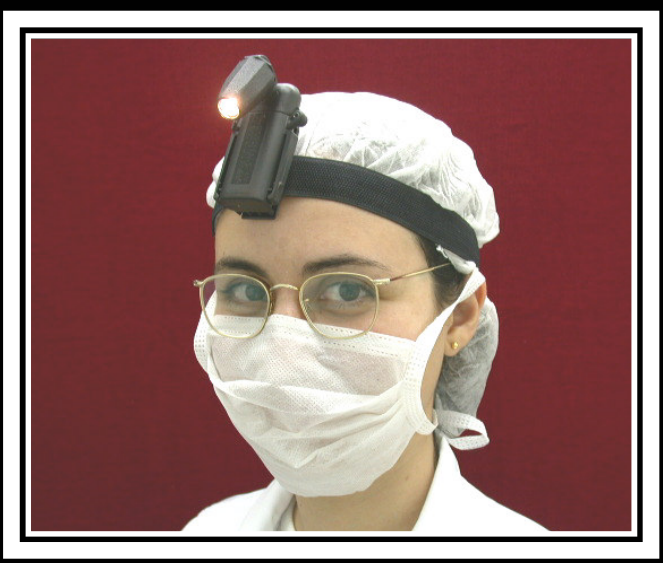

Figura 2: Luz auxiliar para tratamento

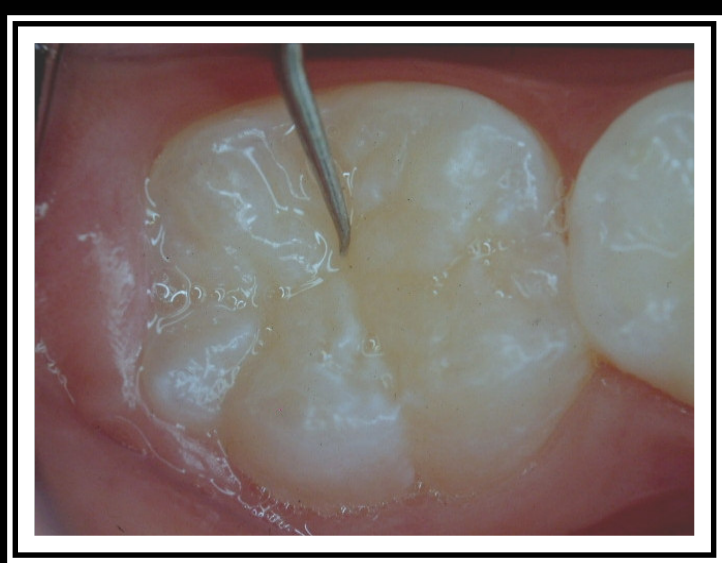

Figura 4: Remoção de indutos alimentares e placa dentária com a sonda exploradora

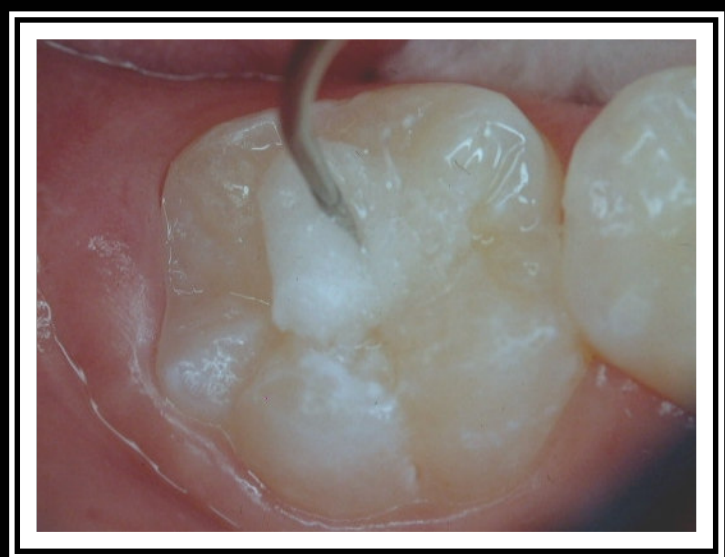

Figura 6: Condicionamento da superfície 


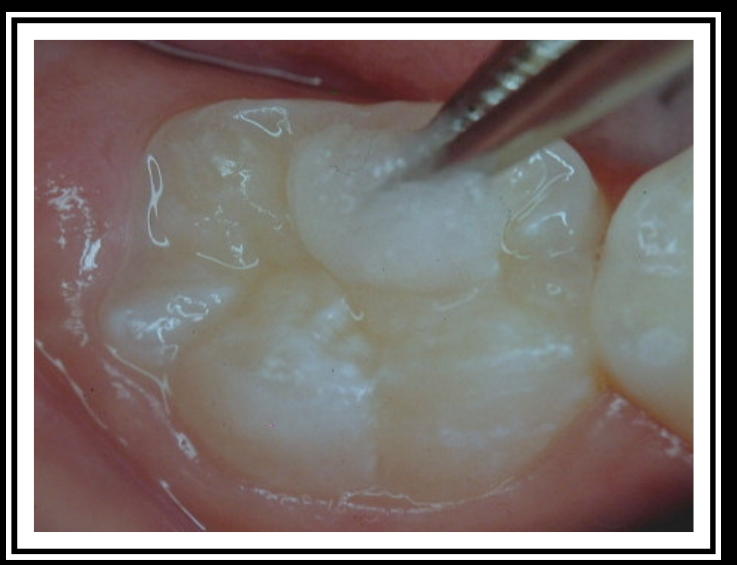

Figura 7: Lavagem da superfície

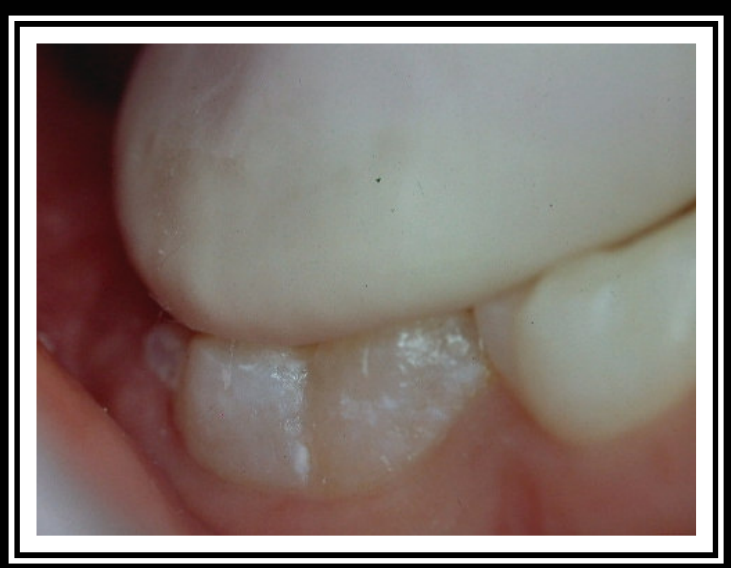

Figura 9: Realização da pressão digital após aplicação do material

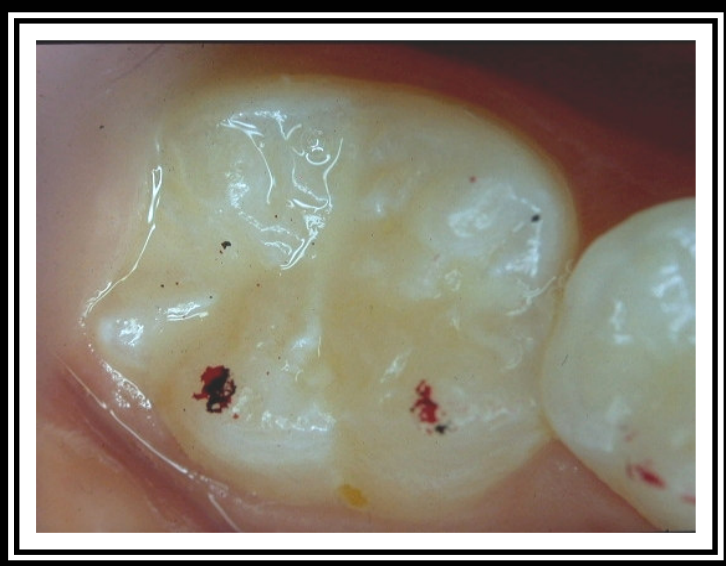

Figura 11: Após remoção dos excessos

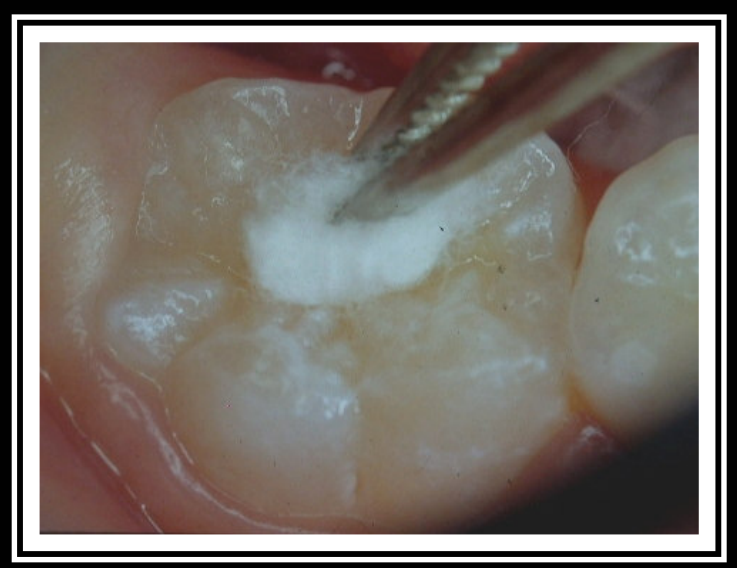

Figura 8: Secagem da superfície

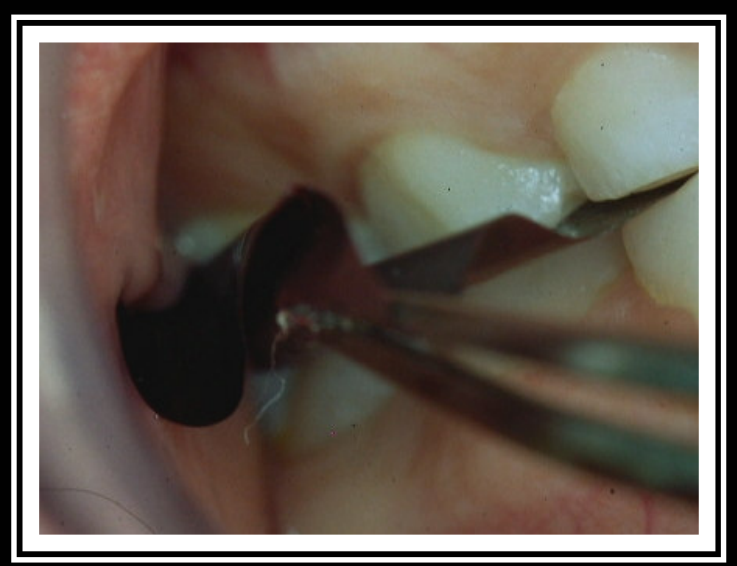

Figura 10: Checagem da oclusão

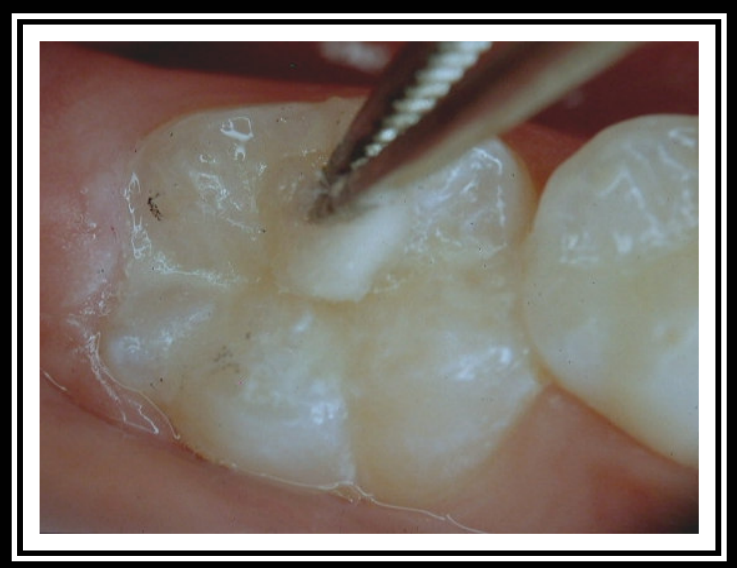

Figura 12: Aplicação do protetor superficial 


\subsection{2 - Avaliação clínica}

A avaliação clínica dos selamentos foi realizada através de exames clínicos após 12 e 36 meses de sua aplicação, por dois cirurgiões-dentistas. Fotografias também foram tiradas em cada avaliação. Os critérios utilizados para a avaliação foram a retenção do material e a presença ou não de lesão de cárie. Avaliações duplicadas foram realizadas em $10 \%$ da amostra com intervalo de 1 semana para que se pudesse obter o índice de concordância intra e interexaminadores.

Os escores de avaliação foram os seguintes ${ }^{29,30}$ :

0 = retenção completa do selante, sem presença de cárie

1 = retenção parcial do selante, sem presença de cárie

2 = retenção parcial do selante, com presença de cárie

3 = perda total do selante, sem presença de cárie

4 = perda total do selante, com presença de cárie

5 = dente restaurado

Os escores 0, 1 e 3 representam sucesso do selamento (ausência de cárie), enquanto que 2, 4 e 5 representam insucesso.

Quando existiu discordância entre os examinadores uma avaliação das fotografias foi realizada e os mesmos chegaram a um consenso.

Após a determinação e tabulação dos escores foram calculadas as porcentagens de sucesso (escore 0, 1 e 3) e insucesso (escores 2, 4 e 5).

Com o intuito de avaliar a possível presença de remanescentes de CIV no fundo das fossas e fissuras ${ }^{6,59}$, no controle de 36 meses foram realizadas moldagens em $10 \%$ da amostra (selecionada aleatoriamente) para avaliação ao microscópio eletrônico de varredura. Esta moldagem foi feita com uma silicona 
de adição (Flexitime, Heraeus Kulzer). Primeiramente foi usado o material "pesado" e depois de realizado um alívio o material "leve" era colocado. A primeira moldagem foi feita com o intuito de limpar a superfície dentária. A segunda moldagem, mais cuidadosa, seria utilizada a obtenção das réplicas. Para confeccioná-las, os moldes foram vazados com a resina epóxica Poly Bed 812 e deixados em estufa a $37^{\circ} \mathrm{C}$ por 48 horas para que tomassem presa.

Depois das réplicas estarem prontas, elas permaneceram na estufa até que fossem metalizadas (Metalizador MED 010, Balzers). A análise microscópica foi realizada no MEV DSM 900, Zeiss (NAP/MEPA - ESALQ/USP) seguindo as orientações contidas no Manual do Curso Introdutório de Microscopia Eletrônica de Varredura ${ }^{47}$. Após a análise de todas as réplicas, as melhores imagens foram salvas em disquete através do programa DSM Image Transfer v.72@1996 LEO e algumas delas estão no capítulo Resultados.

\section{3-ANÁLISE ESTATÍSTICA}

Os dados obtidos foram analisados pelo teste Qui-quadrado para determinação de diferenças significantes entre os índices de sucesso (\% de dentes livres de cárie) dos dois materiais e o teste de Mann-Whitney foi utilizado para comparar o resultado da retenção entre os dois materiais. O nível de significância adotado foi de $p<0,05$.

O grau de concordância dos examinadores foi avaliado pelo índice Kappa. 
5. RESULTADOS 


\section{RESULTADOS}

Os índices iniciais de placa, sangramento, CPOD e ceod estão distribuídos na Tabela 1, enquanto que a distribuição da amostra de acordo com a posição do dente no arco se encontra na Tabela 2.

Tabela 1. Condições inicias da saúde bucal das crianças antes do início do estudo (distribuição dos índices de placa, sangramento, CPOD e ceod)

\begin{tabular}{c|c|c|c|c}
\hline Índice & Placa visível $\pm d p$ & Sangramento $\pm d p$ & $C P O D \pm d p$ & $c e o d \pm d p$ \\
\hline $\begin{array}{l}\text { Valores } \\
\text { iniciais }\end{array}$ & $54,7 \% \pm 25,0$ & $21,3 \% \pm 19,5$ & $0,9 \pm 1,4$ & $2,3 \pm 2,7$ \\
\hline
\end{tabular}

Tabela 2. Distribuição da amostra de acordo com o dente selado.

\begin{tabular}{c|c|c|c|c|c}
\hline Dente & $\mathbf{1 6}$ & $\mathbf{2 6}$ & $\mathbf{3 6}$ & $\mathbf{4 6}$ & Total \\
\hline$n$ & 38 & 37 & 37 & 38 & 150 \\
\hline
\end{tabular}

O tempo médio para a realização dos selantes foi de 10 minutos e 15 segundos, sendo que o tempo para a realização das fotografias foi descontado para não influenciar no tempo total do tratamento.

O resultado das avaliações em duplicata mostrou bons valores de reprodutibilidade. O Kappa intra-examinador variou de 0,78 a 0,89 e o Kappa inter-examinadores foi de 0,81 .

No controle de 12 meses, 38 crianças $(90,7 \%)$ foram examinadas (136 selantes), as 4 crianças restantes mudaram-se de Bauru e foram excluídas do estudo. Neste período todos os dentes selados apresentaram-se livres de cárie e 2 deles foram restaurados com amálgama. O índice de sucesso neste período foi de $98,5 \%$. Os resultados da avaliação de 12 meses podem ser 
observados na Tabela 3 e na Figura 13. O teste Qui-quadrado $\left(X^{2}=0,478\right.$, $\mathrm{p}=0,489$ ) mostrou não haver diferença estatisticamente significante entre os dois materiais quanto ao sucesso (\% dentes livres de cárie) do tratamento. O teste de Mann-Whitney $(U=2271,5, p=0,844)$ mostrou que também não existiu diferença estatisticamente significante quanto à retenção entre os dois CIV testados no período de 1 ano.

O segundo período de controle (36 meses) foi mais longo que o primeiro (12 meses) pois as 37 crianças examinadas (132 selantes) estavam distribuídas em 12 escolas e 2 delas haviam desistido de estudar, dificultando um pouco o transcorrer da avaliação. No controle de 36 meses, 2 dentes no grupo do ChemFlex apresentaram-se com perda total do selante e cárie e 12 dentes receberam outros tipos de tratamento odontológico sendo que destes, 6 receberam selante resinoso, 2 receberam restauração de amálgama e 4 dentes receberam restauração de resina composta. Os dentes que foram selados com material resinoso foram excluídos da amostra por não termos condição de avaliar se houve ou não o desenvolvimento de cárie oclusal nos mesmos. Consideramos portanto um índice de sucesso de 93,7\%. Os resultados da avaliação de 36 meses podem ser observados na tabela 4 e na figura 13.

Neste período estudado, os testes estatísticos mostraram não haver diferença significante entre os dois materiais testados, tanto na retenção (Mann-Whitney $U=2155,5, p=0,904)$ quanto na prevenção de cárie $\left(X^{2}=0,160\right.$, $\mathrm{p}=0,688)$ neste período testado.

Os escores de avaliação estão representados nas Figuras de 14 a 18. Embora a lista de escores retrate 6 diferentes situações clínicas diferentes, neste estudo uma destas não foi encontrada (escore 2). 
A avaliação das réplicas $(n=14)$ ao $M E V$ mostrou que a maioria dos dentes $(92,8 \%)$ apresentava remanescentes de CIV no fundo das fossas e fissuras independente do material utilizado para o selamento. Pode-se observar 3 pares de fotografias e respectivas micrografias nas Figura 19, 20 e 21 .

Tabela 3. Distribuição da amostra de acordo com os escores de avaliação e o material utilizado na avaliação de 12 meses.

\begin{tabular}{|c|c|c|c|c|c|c|c|}
\hline $\begin{array}{c}\text { Escore } \\
\\
N^{o} \\
\text { selamentos }\end{array}$ & 0 & 1 & 2 & 3 & 4 & 5 & Total \\
\hline ChemFlex & $\begin{array}{c}9 \\
13,4 \%\end{array}$ & $\begin{array}{c}19 \\
28,4 \%\end{array}$ & - & $\begin{array}{c}38 \\
56,7 \%\end{array}$ & - & $\begin{array}{c}1 \\
1,5 \%\end{array}$ & 67 \\
\hline Vidrion $R$ & $\begin{array}{c}4 \\
5,8 \%\end{array}$ & $\begin{array}{c}26 \\
37,7 \%\end{array}$ & - & $\begin{array}{c}38 \\
55,1 \%\end{array}$ & - & $\begin{array}{c}1 \\
1,4 \%\end{array}$ & 69 \\
\hline
\end{tabular}

Tabela 4. Distribuição da amostra de acordo com os escores de avaliação e o material utilizado na avaliação de 36 meses.

\begin{tabular}{c|c|c|c|c|c|c|c}
\hline $\begin{array}{c}\text { Escore } \\
\boldsymbol{N}^{\boldsymbol{0}}\end{array}$ & $\mathbf{0}$ & $\boldsymbol{1}$ & $\mathbf{2}$ & $\mathbf{3}$ & $\mathbf{4}$ & $\mathbf{5}$ & Total \\
selamentos & - & 16 & - & 41 & 2 & 6 & 65 \\
\hline ChemFlex & $24,6 \%$ & & $63,1 \%$ & $3,1 \%$ & $9,2 \%$ & \\
\hline Vidrion R & - & 14 & & 47 & & 6 & 67 \\
\end{tabular}




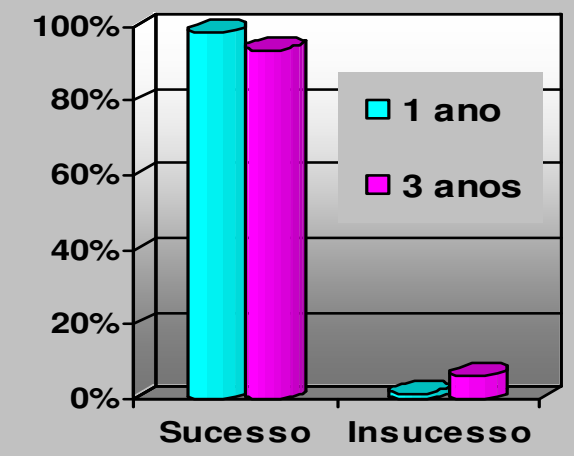

Figura 13: Índice de sucesso e insucesso do tratamento aos 12 e 36 meses.

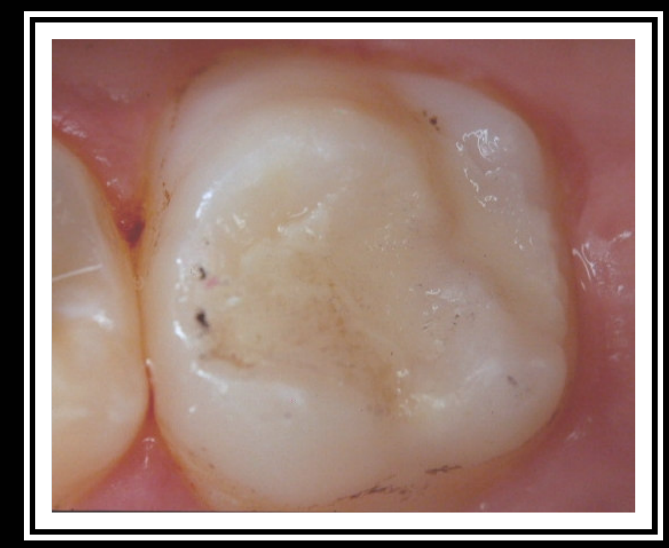

Figura 14: Escore 0
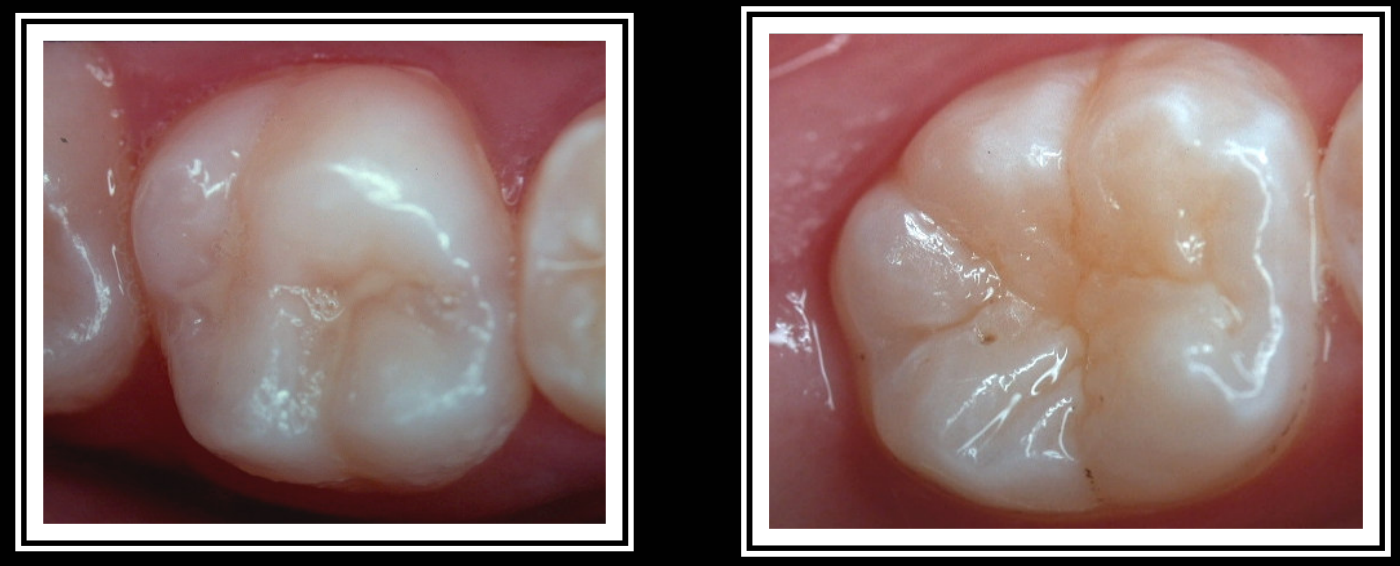

Figura 15: Escore 1

Figura 16: Escore 3
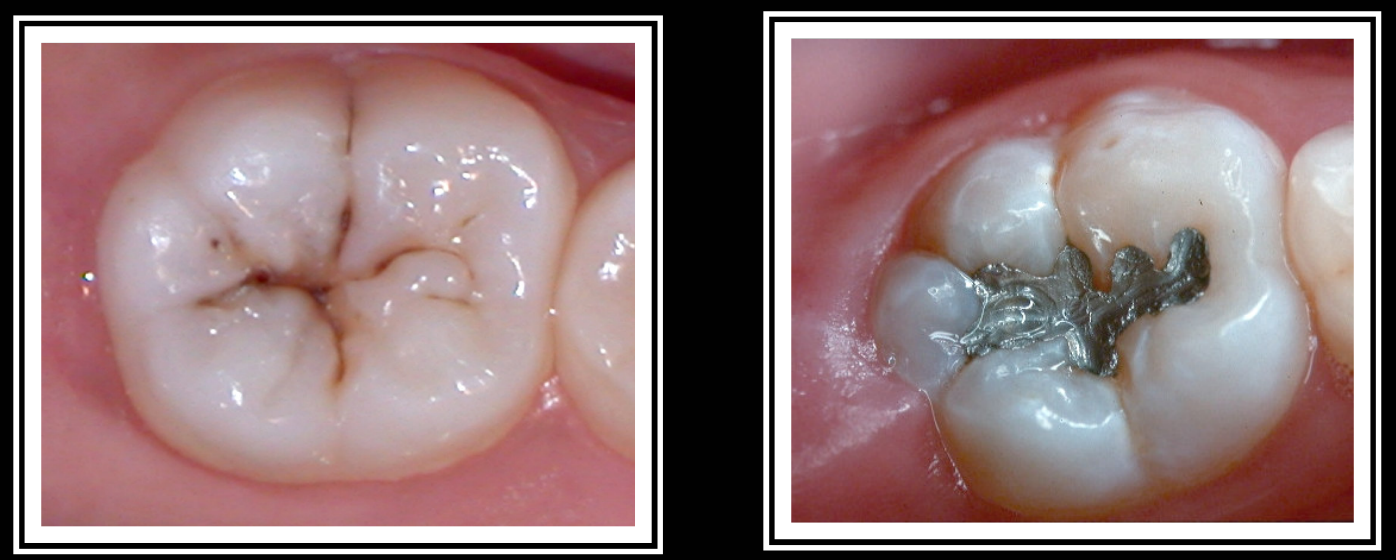

Figura 17: Escore 4

Figura 18: Escore 5 

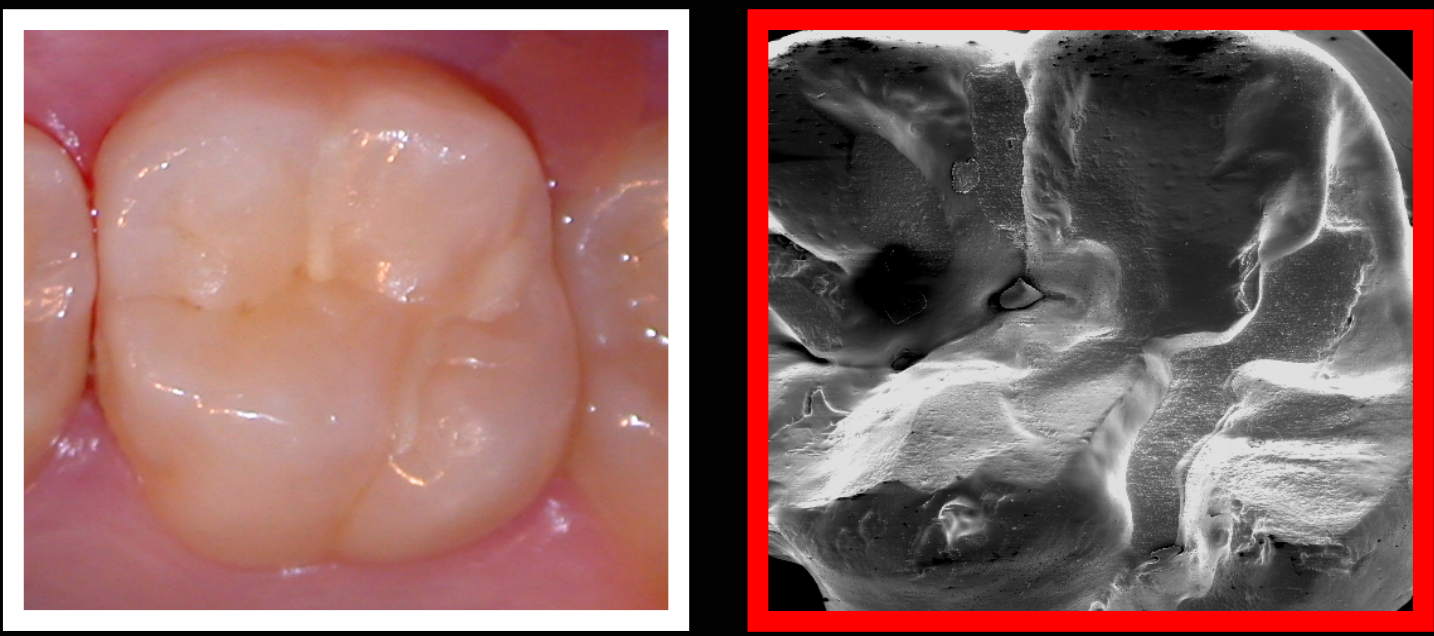

Figura 19: Fotografia clínica e respectiva fotomicrografia de um dente que foi classificado clinicamente com escore 1 (perda parcial do selante sem a presença de cárie). Podemos observar presença de CIV até a embocadura do sulco distal e no sulco entre as cúspides vestibulares

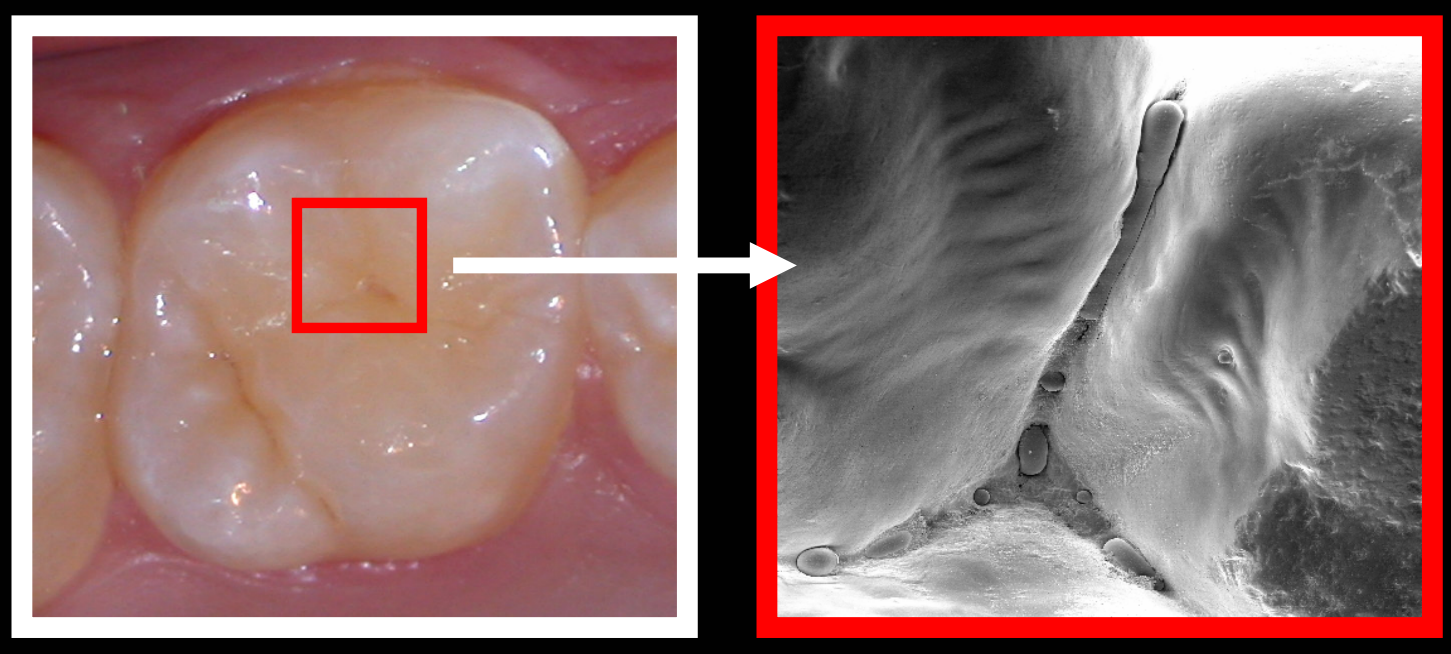

Figura 20: Fotografia clínica e respectiva micrografia de um dente que foi classificado clinicamente com escore 3 (perda total do selante sem a presença de cárie). Podemos observar presença de restos de CIV no fundo das fossas e fissuras
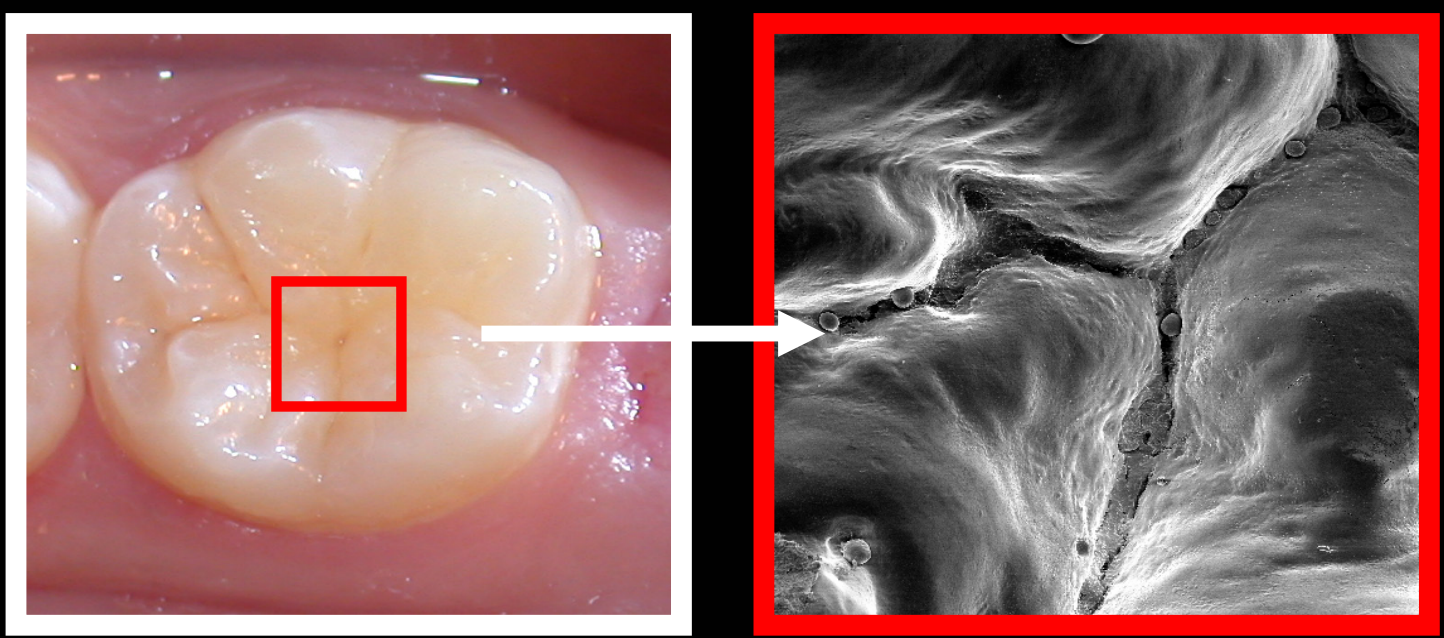

Figura 21: Fotografia clínica e respectiva micrografia de um dente que foi classificado clinicamente com escore 3 (perda total do selante sem a presença de cárie). Podemos observar presença de restos de CIV no fundo das fossas e fissuras 


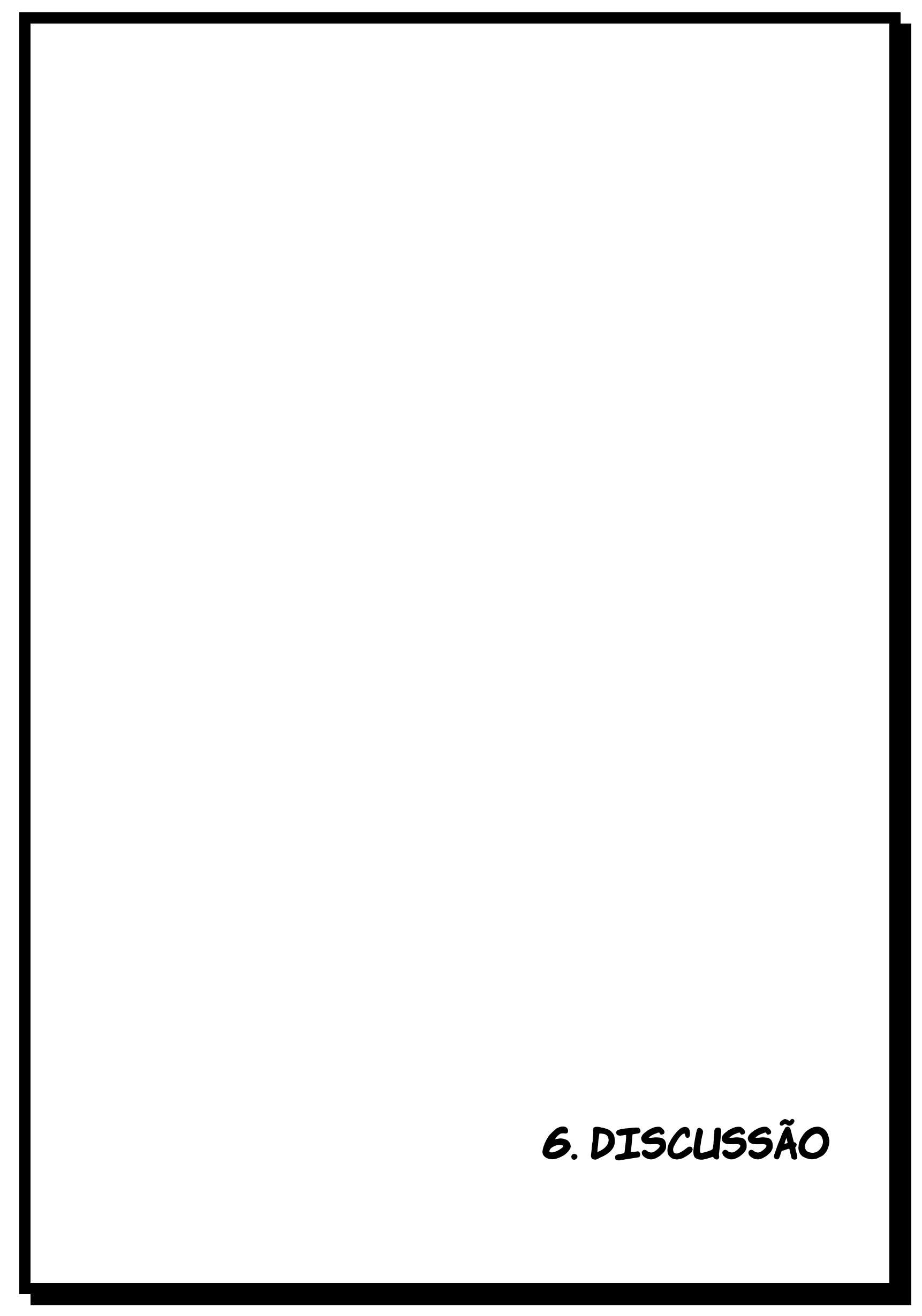




\section{DISCUSSÃO}

Durante as últimas décadas, pesquisas científicas têm nos fornecido dados para um melhor entendimento sobre o processo da cárie dentária. Houve um aumento no conhecimento do mecanismo des/remineralização, da progressão da lesão de cárie, do papel das bactérias e do flúor. Todas estas informações permitiram que o cuidado com a saúde bucal pudesse ser mais direcionado à prevenção.

Por outro lado, em países em desenvolvimento, uma grande parte da população continua sem acesso a nenhum tipo de cuidado odontológico. Muitas vezes o tratamento só é realizado quando a única opção é a exodontia ${ }^{13}$. Vários são os fatores que contribuem para este fim: recursos financeiros insuficientes em Saúde Pública, impossibilidade de acesso à Odontologia privada, necessidade de equipamentos e materiais sofisticados. Frente a essa realidade, têm-se buscado alternativas para proporcionar atendimento odontológico a um maior número de pessoas.

O Tratamento Restaurador Atraumático (ART) surgiu com este propósito e vem mostrando bons resultados $24,26,27,29,30$, tornando 0 tratamento odontológico acessível para as populações economicamente desfavorecidas. As vantagens deste tratamento são várias: uso de instrumentos manuais relativamente de baixo custo, possibilidade de controle da dor, uso de material biocompatível e sobretudo, a existência de uma combinação de medidas preventivas e curativas ${ }^{24,25}$.

O uso do cimento de ionômero de vidro como material restaurador e selador também é considerado um ponto positivo do tratamento, pois este material possui muitas propriedades favoráveis, tais como: biocompatibilidade 
com os tecidos dentários, adesividade, reação química de ativação, coeficiente de expansão térmica similar ao do dente e liberação de flúor. Atualmente, o CIV é o único material que aumenta a resistência do dente aos ácidos ${ }^{18}$. Novos cimentos foram desenvolvidos exclusivamente com o intuito de adequar este material ao tipo de tratamento preconizado pelo ART. Estes CIV específicos para a técnica, chamados de CIV de alta viscosidade, tem se mostrado com adesão efetiva $^{44}$, liberação satisfatória de íons flúor $^{33,79}$, além de serem mais resistentes ao desgaste ${ }^{19,94}$ do que os convencionais. Apesar destes dados, ainda existe a necessidade do desenvolvimento de materiais mais resistentes à fratura e ao desgaste e com maior adesividade para que a longevidade de restaurações de múltiplas superfícies (restaurações complexas) seja maior ${ }^{42}$. Outro ponto a ser melhorado nos CIV's atuais é a deficiência em selar as margens contra a penetração das bactérias, além da sensibilidade à dessecação ${ }^{5}$.

Além do tratamento restaurador, dentro do protocolo do ART também existem ações preventivas tais como: orientação da dieta, instrução sobre higiene bucal e aplicação de selantes oclusais ${ }^{25}$. Estes últimos vêm se mostrando efetivos na prevenção das cáries oclusais principalmente no período de erupção dos molares permanentes (com duração de 1 ano a 1,5) quando eles se mostram mais susceptíveis. Durante este período, o esmalte dentário não se encontra maturado, a oclusão ainda não está estabelecida para promover a autolimpeza, a remoção da placa bacteriana com a escovação é ineficiente, além de muitos pacientes e seus responsáveis também desconhecerem que um novo dente (permanente) está emergindo na cavidade bucal. Frente a todos estes agravantes, vários autores $6,8,12,26,38,52,59,63,64$ ao 
longo dos últimos anos vêm estudando o comportamento dos selantes oclusais como um método preventivo de cárie nestas superfícies, principalmente os selantes com CIV. Apesar do menor índice de retenção destes, parece não haver diferença no efeito preventivo de cárie a longo prazo $6,59,63,64,73,82$.

Este trabalho avaliou o comportamento clínico de selamentos oclusais realizados pela técnica do ART com 2 tipos de CIV em pacientes com alto índice de cárie. Na amostra estudada o índice CPOD foi de 0,9, embora numericamente aparente ser baixo, esta percepção muda quando a idade dos pacientes é considerada. Na faixa etária estudada (6 a 8 anos), os $1^{\text {os }}$ molares permanentes estão recém-erupcionados e a leitura do CPOD 0,9 evidencia que numa fase precoce da erupção praticamente 1 deles foi considerado cariado. Tal condição confere um grau de ineditismo ao trabalho, uma vez que a maioria dos estudos encontrados na literatura relata índices CPOD baixos em pacientes com maior idade (CPOD de 1,1 e idade média de 13,9 anos ${ }^{29}$, CPOD de 0,69 e idade média de 14,1 $\operatorname{anos}^{30}$ e CPOD de 0,6 e idade entre 12-13 $\left.\operatorname{anos}^{41}\right)$. Outro parâmetro para se considerar estes pacientes de alto índice de cárie é o ceod de 2,3. Enfatizando o estado de saúde bucal desses pacientes, encontrou-se um IPV de 54,7\% e um ISG de $21,3 \%$.

O tempo gasto para a realização dos selantes (10min 15s) está em acordo com a literatura existente que relata $9,3^{26}, 9,4^{29}$ e $10,7^{30}$ minutos.

A porcentagem de alunos examinados neste estudo nos controles de 12 e 36 meses $(90,7 \%$ e $88,3 \%$ respectivamente) foi boa se comparada à porcentagem em outros trabalhos que geralmente é menor do que $70 \%{ }^{26,30,66}$. Gao et al. ${ }^{32}$ por exemplo conseguiram avaliar $67 \%$ da amostra inicial aos 12 meses e apenas $24,5 \%$ aos 36 . A maioria dos autores relata que a grande 
perda no acompanhamento das crianças se dá devido a mudança de escola e no nosso caso, todas as crianças que continuavam a residir no mesmo município, embora muitas tivessem mudado de escola, foram avaliadas devido ao esforço dos pesquisadores em encontrá-las.

Ao se comparar os resultados de retenção dos selamentos deste trabalho com o de outros onde os procedimentos foram realizados em clínica, com equipamento odontológico convencional, existem relatos de superioridade destes em alguns trabalhos ${ }^{52,59,87}$ contudo, também existem relatos na literatura com resultados semelhantes para as duas técnicas ${ }^{6,64,70}$. Esta divergência de resultados pode ser explicada por vários fatores: trabalhos que usaram CIV específico para selamento oclusal (Fuji III) apresentaram resultados de retenção mais baixos, já aqueles que usaram CIV restaurador apresentaram melhores resultados. Outro fator a ser analisado é o tratamento da superfície oclusal antes da aplicação do selante, o qual é um importante determinante na retenção do mesmo. O tratamento do substrato que vai receber o CIV interfere na adesão do mesmo. Já foi constatado que a limpeza da superfície dentária com pedra pomes ou jato de bicarbonato de sódio produz condições favoráveis à adesão do cimento de ionômero de vidro ${ }^{1}$. Os condicionadores de superfície também alteram os valores de adesão do CIV à estrutura dentária. Os condicionadores mais efetivos são os de alto peso molecular ${ }^{71}$. Outro fator que pode variar a força de adesão do CIV é a dificuldade em se obter um bom molhamento e interação química suficiente entre o esmalte e o $\mathrm{CIV}^{46}$.

Apesar de toda especulação existente em relação ao índice de retenção dos selamentos oclusais, a principal razão pela qual ele é aplicado não pode ser esquecida: a prevenção das cáries ${ }^{28}$. Olhando por este ponto de vista, este 
estudo está de acordo com outros ${ }^{6,52,59,63,64,89}$ da literatura que mostram que uma grande porcentagem dos dentes selados com CIV se apresenta livre de cárie nas avaliações longitudinais. Os motivos da eficácia em prevenir cáries mesmo na ausência clínica dos selantes de CIV também já foram muito estudados e parece estar relacionado ao nível de flúor aumentado no esmalte e na placa dentária e ao material residual que permanece nas fossas e fissuras que permanece sem ser detectado clinicamente ${ }^{74}$. A melhor mineralização do esmalte do dente recém-erupcionado e a constante liberação de flúor pelo CIV resultam em uma estrutura dentária mais madura e ácido resistente, mesmo após a perda relativamente precoce do material ${ }^{73}$. Tendo como base os relatos sobre a presença de CIV no fundo das fossas e fissuras mesmo quando clinicamente verifica-se ausência do selante ${ }^{6,59}$, foram realizadas as moldagens dos dentes e avaliação das réplicas ao microscópio eletrônico. Os resultados obtidos confirmam os de outros autores ${ }^{6,59}$ que observaram estes remanescentes de material.

Outro fato que pode auxiliar na prevenção de cárie pelos selamentos ionoméricos é o fato deste material possibilitar menor crescimento de $\mathrm{S}$. mutans em sua superfície do que selantes resinosos como o Delton ${ }^{83}$ por exemplo.

Quando se comparou o índice de retenção dos selantes deste trabalho com outros realizados pela técnica do ART observou-se que também existem diferenças. No presente estudo houve uma perda maior do material nas fossas e fissuras do que no estudo de FRENCKEN; MAKONI; SITOLE ${ }^{29}$ (1996), que obtiveram $60,3 \%$ de retenção total (RT) e 13,4\% de retenção parcial (RP) aos 12 meses e no estudo de FRENCKEN et al. $^{23}(1994)$ que relataram índice de 
sucesso na retenção de selantes em dentes permanentes de $78 \%$. Por outro lado se comparados aos relatados por MOTSEI; KROON; HOLTSHOUSEN em $2001^{61}(10,4 \%)$, observa-se que os resultados do presente estudo mostram-se superiores (média de 42,7\% de retenção). Após 36 meses de avaliação, os resultados deste estudo $(22,7 \%$ de $\mathrm{RP})$ mostram-se inferiores aos relatados por FRENCKEN, MAKONI, SITOLE $(1998)^{30}$, FRENCKEN et al. $(1998)^{26}$ e HOLMGREN $(2000)^{41}$. Os resultados destes trabalhos ${ }^{26,30,41}$ se encontram na média reportada por YIP, SMALES $(2002)^{95}$ que é de $70 \%$ (RT e RP). Apesar de ter sido aplicado através da pressão digital, que apresenta bons níveis de penetração do cimento $^{80}$, este estudo apresentou índices mais baixos de retenção, que podem ter tido como causa: a dificuldade de isolamento dos dentes devido ao fato de eles serem recém-irrompidos e conseqüente contaminação com os fluídos bucais, a exposição do CIV à saliva precocemente (sem estar totalmente endurecido) e a aplicação em fissuras não tão profundas. Outra diferença importante que pode ter diminuído o índice de retenção dos selantes neste estudo é a idade dos pacientes atendidos. A grande maioria dos trabalhos que avaliou a performance clínica dos selantes de CIV realizados de acordo com a filosofia do ART foi realizada em pacientes mais velhos, com a média de idade entre 13 e 14 anos $^{26,29,30,41}$ ou em adultos $^{32,38}$. Pacientes de menor idade, entre 6 e 8 anos como os deste trabalho, apresentam algumas características que dificultam o tratamento entre elas: menor abertura da boca devido ao seu tamanho, maior dificuldade para controlar o comportamento, maior dificuldade para o controle da saliva, grau de erupção dos dentes e acesso mais difícil aos 1 os molares por estes serem os dentes posicionados mais posteriormente na cavidade bucal. 
Já o índice de sucesso deste estudo, representado pela porcentagem de dentes selados sem cárie, está alinhado aos outros resultados da literatura que avaliaram o selamento realizado pela técnica do ART. Após 3 anos da aplicação dos selantes, $93,7 \%$ dos dentes selados se mostraram livres de cárie, sendo que em outros resultados publicados este índice varia entre $91,6 \%{ }^{26}, 96,3 \%{ }^{30}$ e $98 \%{ }^{41}$.

Ao se comparar o desempenho clínico dos dois materiais utilizados neste estudo nota-se não haver diferença entre eles, apesar de serem materiais diferentes: um cimento restaurador convencional (Vidrion R/SS White) e outro de alta viscosidade (ChemFlex/Dentsply). Estes resultados devem ser encarados de maneira positiva pois com o uso de um CIV restaurador fabricado no Brasil (Vidrion R/SSWhite) apresentando resultados promissores, poderá tornar esta técnica acessível a uma parcela maior da população, pois o outro CIV utilizado (ChemFlex/SSWhite) é importado e tem um custo muito superior.

Outro ponto a ser ressaltado é que, embora a técnica empregada seja simplificada quando comparada às técnicas convencionais, atenção deve ser dada ao treinamento e capacitação da equipe que irá realizá-la ${ }^{23,25}$. Os fracassos na aplicação da técnica geralmente estão relacionados à negligência de passos operatórios.

Medidas que visam a prevenção da cárie dentária vem sendo propostas há décadas, dentre elas temos os programas baseados na remoção mecânica da placa dentária pelo profissional ${ }^{9,10,11,14,35,48}$ (cujo custo é alto e a dependência do profissional também), aplicação de flúor ${ }^{65,96}$, aplicação de verniz de clorexidina ${ }^{7}$, aplicação de selantes oclusais ${ }^{6,8,12,21,59}$ e também 
aqueles que combinam várias medidas preventivas ${ }^{50,82}$. Os programas baseados na profilaxia profissional periódica mostram resultados muito efetivos na prevenção da cárie $9,14,35,50,69$, mas por outro lado são impraticáveis neste momento na Saúde Pública brasileira pelo seu alto custo. Desta maneira precisamos adequar os programas preventivos à nossa realidade e conseguir bons índices na prevenção da cárie dentária. Este trabalho apresenta uma alternativa quanto à prevenção das cáries oclusais e apesar de os selamentos oclusais serem só parte de um programa preventivo, constitui-se num instrumento importante do armamento contra a cárie e seu uso deve ser considerado na Odontologia Pública. 


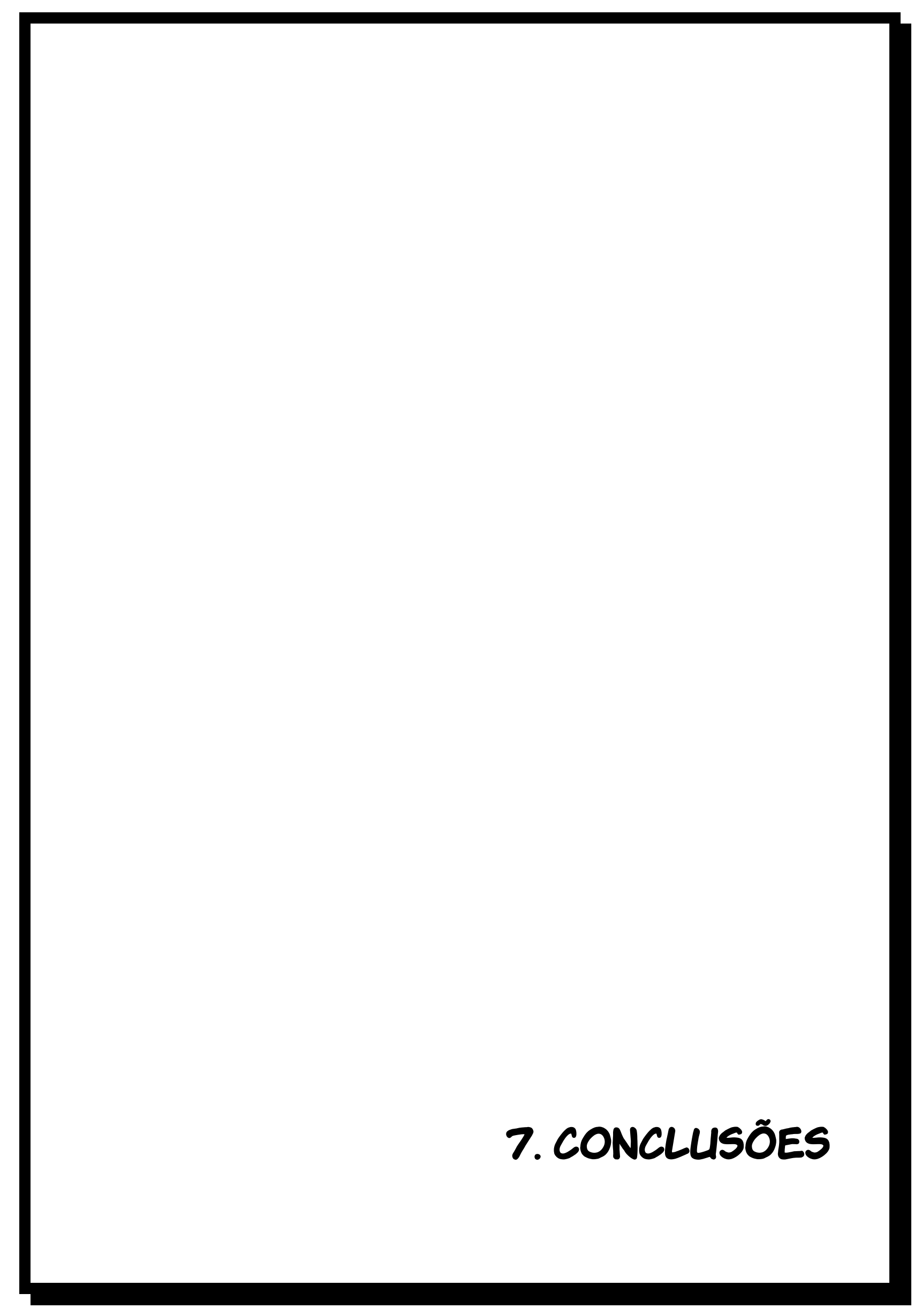




\section{CONCLUSÕES}

Pela metodologia empregada e baseado nos resultados obtidos, constatou-se que o comportamento dos dois materiais testados (Vidrion R/S.S. White e ChemFlex/Dentsply) foi semelhante, tanto na retenção quanto na porcentagem de dentes selados livres de cárie. Desse modo, houve a confirmação das hipóteses nulas.

Apesar dos baixos índices de retenção dos materiais testados, os selamentos realizados através da técnica do ART em $1{ }^{\text {os }}$ molares permanentes recém-erupcionados de pacientes de uma população com alto índice de cárie cumpriram seu objetivo: manter as superfícies oclusais livres de cárie. 


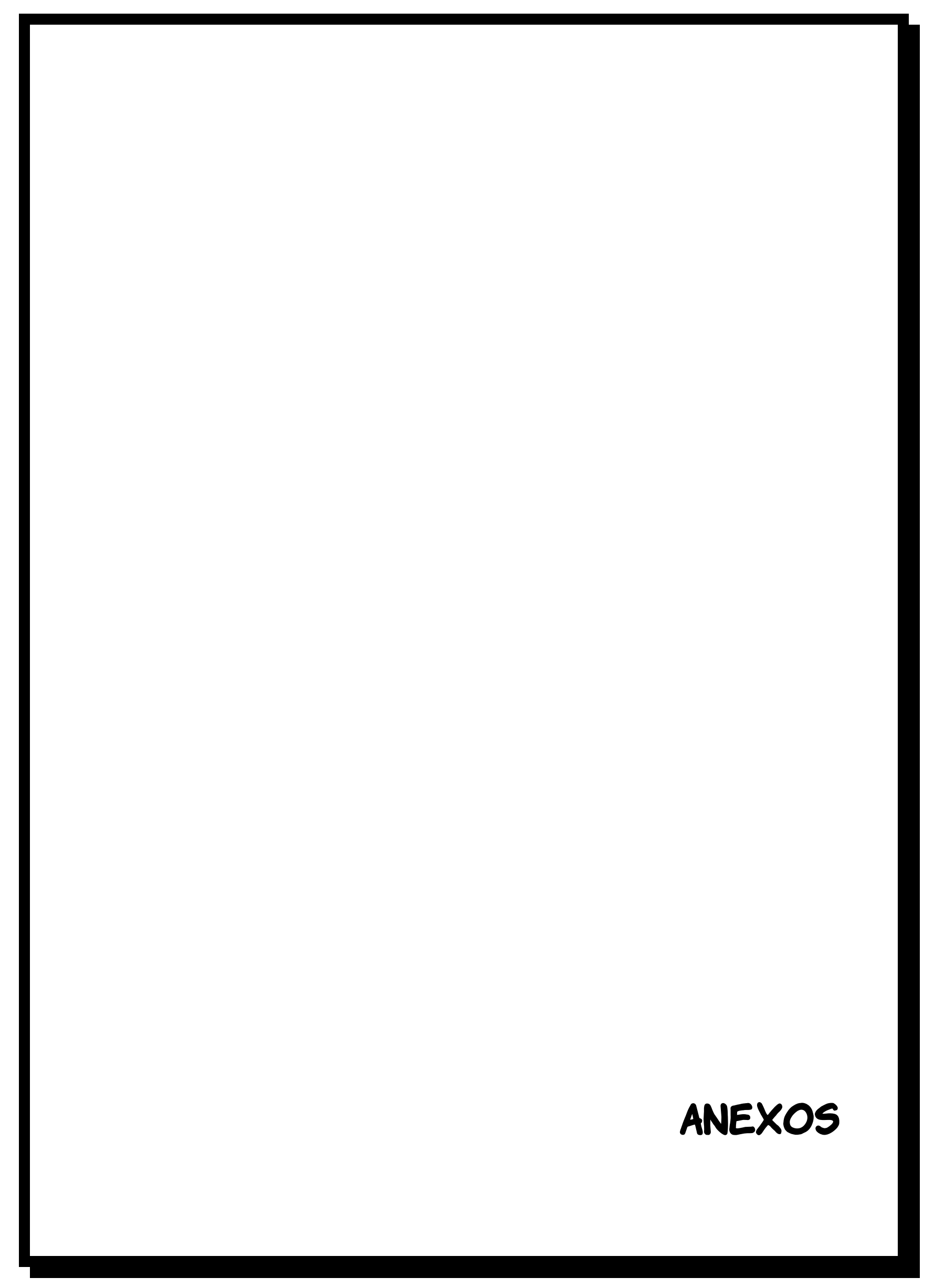


ANEXO 1

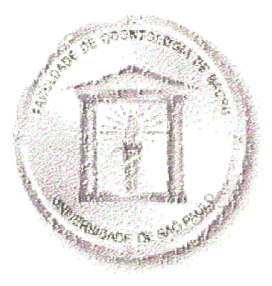

\author{
Universidade de São Paulo \\ Faculdade de Odontologia de Bauru \\ Al. Dr. Octávio Pinhciro Brisolla, 9-75 - Bauru-SP - CEP 17012-101 - C.P. 73 \\ PABX (0XX14)235-8000 - FAX (0XX14)223-4679 \\ Comitê de Ética em Pesquisa
}

Bauru, 12 de dezembro de 2000

$\mathrm{Ilm}^{\mathrm{a}} \mathrm{Sr}^{\mathrm{a}}$

Prof $^{a}$ Dr $^{a}$ Maria Fidela de Lima Navarro

Departamento de Dentística

FOBUSP

Prezada Doutora

O projeto de pesquisa encaminhado a este Comitê de Ética denominado "AVALIAÇÃO DE RESTAURAÇÕES DE CAVIDADE CLASSE I REALIZADAS PELA TÉCNICA DO TRATAMENTO RESTAURADOR ATRAUMÁTICO" de sua autoria foi enviado a um relator para avaliação.

$\mathrm{Na}$ reunião de 30 de novembro, o parecer do relator aprovando o projeto, foi aceito pelo Comitê, considerando que não existem infrações éticas pendentes.

Atenciosamente,

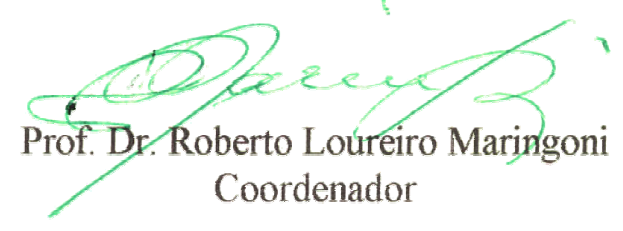


ANEXO 2
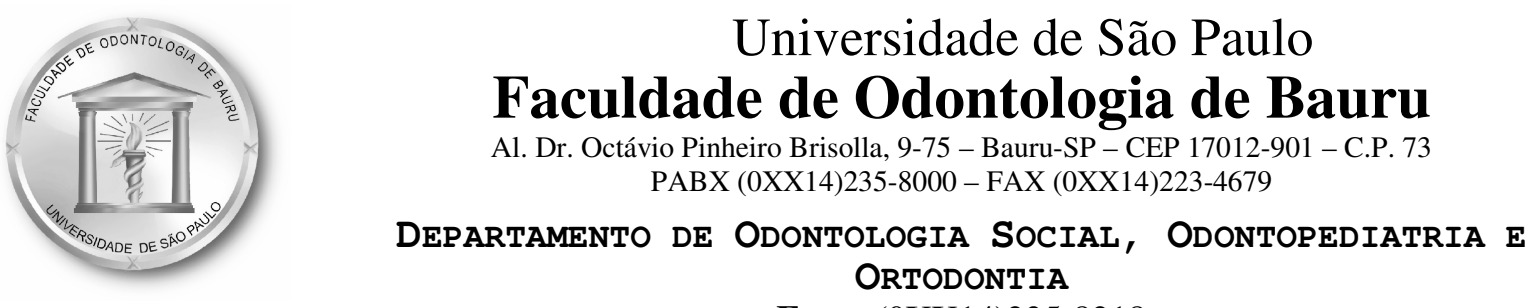

Fone: (0XX14)235-8218

\section{Aos Pais e /ou Responsáveis:}

Iniciaremos um tratamento odontológico em seu filho (a) que consiste na limpeza dos dentes e aplicação de um material que libera flúor para prevenir a cárie. Este tratamento vem sendo realizado em vários países com grande índice de sucesso e nosso objeto é fazer uma avaliação aqui no Brasil.

Se houver outros tratamentos que não possam ser realizados em ambiente escolar ou se ocorrer qualquer problema após o tratamento, o aluno será encaminhado para a Faculdade de Odontologia de Bauru e será atendido pelo Cirurgião-Dentista responsável.

Não haverá nenhum risco à saúde geral dos pacientes pois serão utilizados instrumentais estéreis e material descartável. Os participantes têm liberdade para deixar a pesquisa a qualquer momento sem qualquer prejuízo.

Devemos também esclarecer, se caso autorize o tratamento, que este é um estudo que exigirá retornos ao dentista para acompanhamento em períodos pré-determinados (12 e 36 meses) e que a autorização do mesmo permite a divulgação dos resultados no meio científico.

Este estudo é um trabalho que visa melhorar a condição de saúde bucal de nossa comunidade e sua colaboração é de extrema importância.

Agradeço a atenção e a colaboração.

Ana Luiza Falavinha Vieira

C.D. Responsável pela Pesquisa 
ANEXO 3

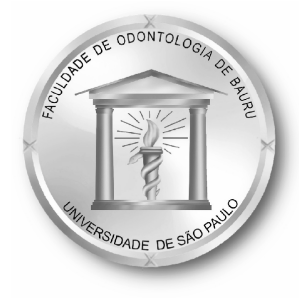

\author{
Universidade de São Paulo \\ Faculdade de Odontologia de Bauru \\ Al. Dr. Octávio Pinheiro Brisolla, 9-75 - Bauru-SP - CEP 17012-901 - C.P. 73 \\ PABX (0XX14)235-8000 - FAX (0XX14)223-4679 \\ Departamento DE Odonologia SOcial, Odontopediatria E \\ ORTODONTIA \\ Fone: (0XX14)235-8218
}

\title{
Autorização para pesquisa clínica e execução de tratamento
}

Avaliação clínica de selantes oclusais realizados pela Técnica do Tratamento

$$
\begin{gathered}
\text { Restaurador Atraumático } \\
\text { Por meio deste instrumento que atende às exigências legais, o }
\end{gathered}
$$
senhor(a) portador da cédula de identidade $\mathrm{n}^{\mathrm{o}}$ SSP/ ,responsável pelo(a) menor

após a leitura minuciosa da CARTA DE INFORMAÇÃO AO PACIENTE, devidamente explicada pelo(s) profissional(is) em seus mínimos detalhes, ciente dos serviços e procedimentos que serão realizados, não restando quaisquer dúvidas a respeito do lido e explicado, firma se CONSENTIMENTO LIVRE E ESCLARECIDO em concordância para que o menor em questão participe da pesquisa proposta no que the é cabível, conforme a CARTA DE INFORMAÇÃO AO PACIENTE.

Fica claro que o paciente ou seu representante legal podem, a qualquer momento, retirar seu CONSENTIMENTO LIVRE E ESCLARECIDO e deixar de participar do estudo alvo da pesquisa e ciente que todo trabalho realizado se torna informação confidencial, será guardado por força do sigilo profissional ( Art. 9ํ do Código de Ética Odontológica).

Por estarem entendidos e conformados, assinam o presente termo.

Bauru, de 2000. 
ANEXO 4

\section{Ficha de exame clínico}

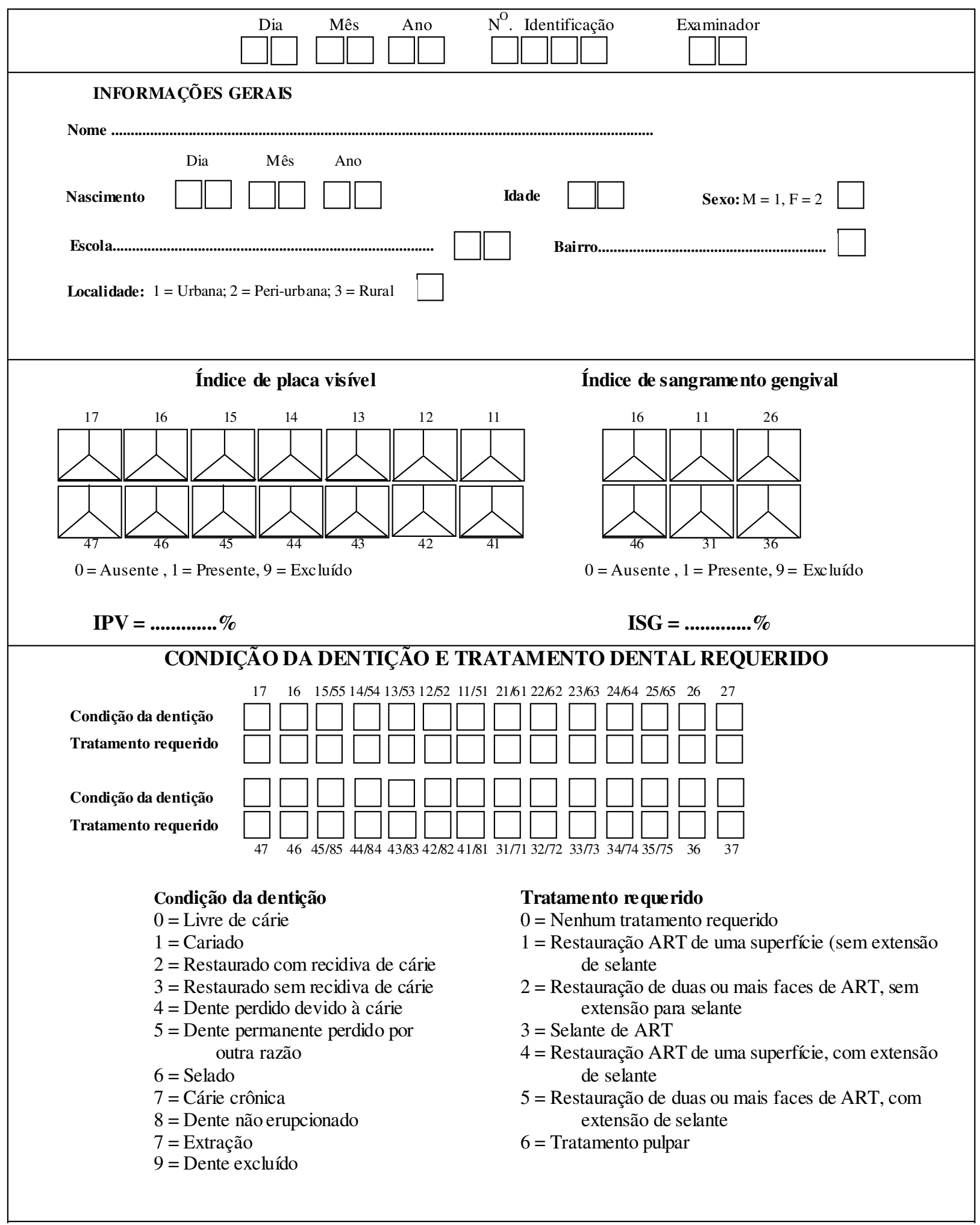




\section{Selamento ART}

ANEXO 5

Escola: E. E. Ayrton Bush

Aluno:.

D.N.:

Endereço

Idade:

Telefone(......).

\section{Procedimentos}

Data: / /

16:

26:

46:

36:

\section{Avaliação Clínica}

12 meses

\begin{tabular}{|c|c|c|c|c|c|c|c|}
\hline \multicolumn{2}{|l|}{ D: } & \multicolumn{2}{l|}{ D: } & \multicolumn{2}{l|}{ D: } & \multicolumn{2}{l|}{ D: } \\
\hline 0 & & 0 & & 0 & & 0 & \\
\hline 1 & & 1 & & 1 & & 1 & \\
\hline 2 & & 2 & & 2 & & 2 & \\
\hline 3 & & 3 & & 3 & & 3 & \\
\hline 4 & & 4 & & 4 & & 4 & \\
\hline 5 & & 5 & & 5 & & 5 & \\
\hline
\end{tabular}

36 meses

\begin{tabular}{|c|c|c|c|c|c|c|c|}
\hline \multicolumn{2}{|l|}{ D: } & \multicolumn{2}{l|}{ D: } & \multicolumn{2}{l|}{ D: } & \multicolumn{2}{l|}{ D: } \\
\hline 0 & & 0 & & 0 & & 0 & \\
\hline 1 & & 1 & & 1 & & 1 & \\
\hline 2 & & 2 & & 2 & & 2 & \\
\hline 3 & & 3 & & 3 & & 3 & \\
\hline 4 & & 4 & & 4 & & 4 & \\
\hline 5 & & 5 & & 5 & & 5 & \\
\hline
\end{tabular}




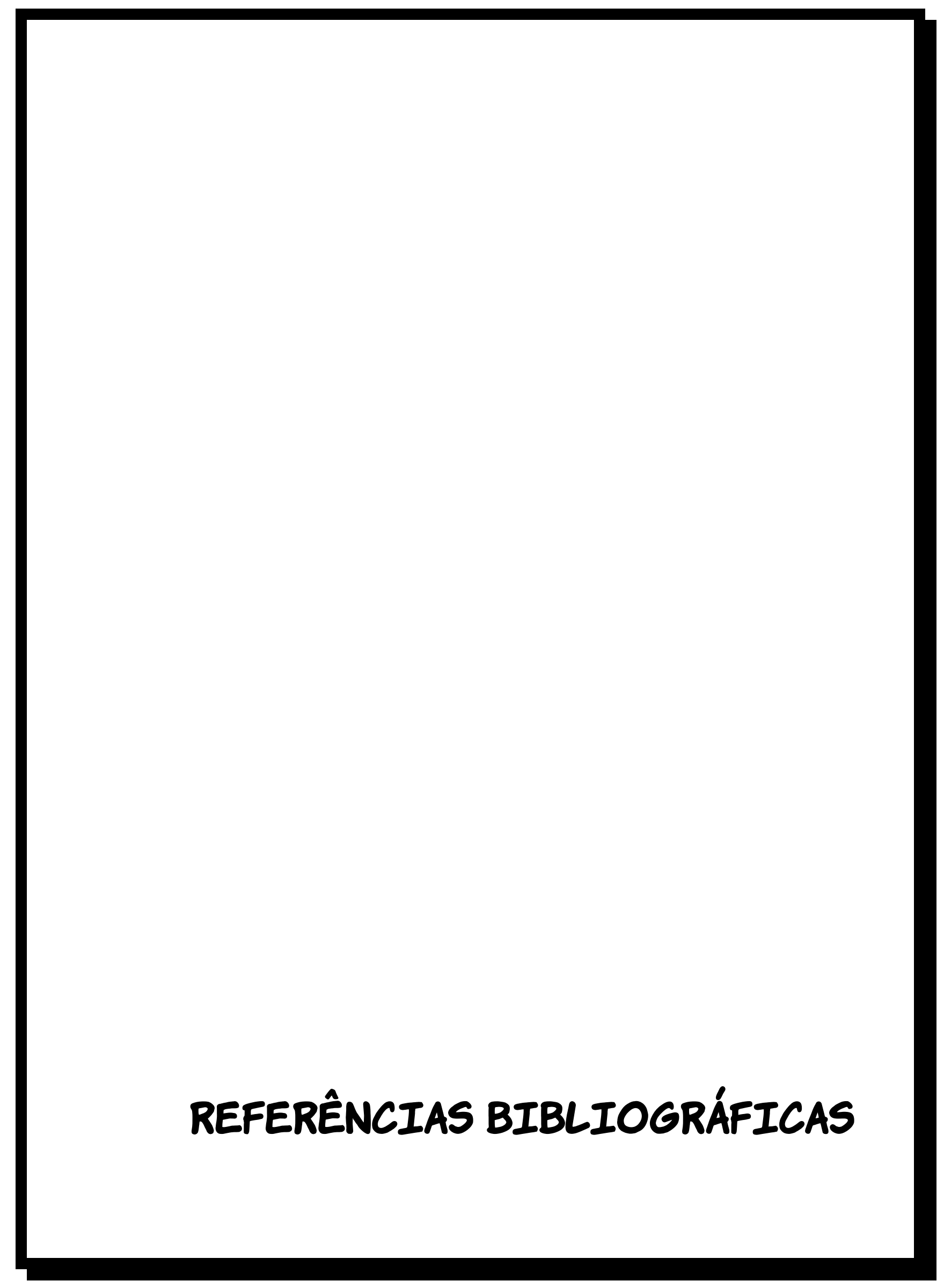




\section{REFERÊNCIAS BIBLIOGRÁFICAS*}

1. ABOUSH, Y.E.Y.; JENKINS, C.B.G. An evaluation of the bonding of glassionomer restoratives to dentin and enamel. Brit. dent. J., v.164, n.5, p.179-84, Sept. 1986.

2. ADDO-YOBO, C.; WILLIAMS, S.A.; CURZON, M.E. Dental caries experience in Ghana among 12-year old urban and rural school children. Caries Res., v.25, n.4, p. 311-4, 1991.

3. AINAMO, J.; BAY, I. Problems and proposals for recording gingivitis and plaque. Int. dent. J., v.25, n.4, p. 229-35, Dec. 1975.

4. AMEROGEN, W.E.; RAHIMTOOLA, S. Is ART really atraumatic? Community Dent. oral Epidem., v.27, n.6, p.431-5, Dec. 1999.

5. ANUSAVICE, K.J. Does ART have a place in preservative dentistry? Community Dent. oral Epidem., v.27, n.6, p.442-8, Dec. 1999.

6. ARANDA, M.; GARCÍA-GODOY, F. Clinical evaluation of the retention and wear of a light-cured pit and fissure glass ionomer sealant. J. clin. pediat. Dent., v.19, n.4, p.273-7, Summer 1995.

7. ARAÚJO, A.M.P.G. et al. Effect of cervitec on mutans streptococci in plaque and on caries formation on occlusal fissures of erupting permanent molars. Caries Res., v.36, n.5, p.373-6, Sep./Oct. 2002.

8. ARROW, P.; RIORDAN, P.J. Retention and caries preventive effects of GIC and a resin-based fissure sealant. Community Dent. oral Epidem., v.23, n.5, p.282-5, Oct. 1995.

\footnotetext{
* Normas recomendadas para uso no âmbito da Universidade de São Paulo, com base no documento "Referências bibliográficas: exemplos" emanado do Conselho Superior do Sistema Integrado de Bibliotecas da USP, em reunião de 20 de setembro de 1990.
} 
9. AXELSSON, P.; LINDHE, J. The effect of preventive program on dental plaque, gingivitis and caries in schoolchildren: results after one year and two years. J. clin. Periodont., v.1, n.2, p.126-38, 1974.

10. AXELSSON, P.; LINDHE, J; WASEBY, J. The effect of various plaque control measures on gengivitis and caries in schoolchildren. Community Dent. oral Epidem., v.4, p.232-9, 1976.

11. BADERSTEN, A.; EGELBERG, J.; KOCH, G. Effect of monthly prophylaxis on caries and gengivitis in schoolchildren. Community Dent. oral Epidem., v.3, p.1-4, 1975.

12. BOKSMAN, L. et al. Clinical evaluation of glass ionomer cement as fissure sealant. Quintessence Int., v. 18, n.10, p.707-9, Oct. 1987.

13. CALDAS, A.F.; MARCENES, W.; SHEIHAM, A. Reasons for tooth extraction in a Brazilian population. Int. dent. J., v.50, n.5, p.267-73, Oct. 2000.

14. CARLSSON, P. et al. Effect of a preventive program on dental caries and mutans streptococci in Polish schoolchildren. Community Dent. oral Epidem., v.16, n.5, p.253-7, 1988.

15. CHIRONGA, L.; MANJI, F. Dental caries in 12-year old urban and rural children in Zimbabwe. Community Dent. oral Epidem., v.17, n.1, p.31-3, Feb. 1989.

16. CHRISTENSEN, G.J. The need for dental caries-preventive restorative materials. J. Amer. dent. Ass., v. 131, n.9, p.1347-9, Sep. 2000.

17. COLE, B.O.I; WELBURY, R.R. The atraumatic restorative treatment (ART) technique: does it have a place in everyday practice? Dent. Update, v.27, n.3, p.118-23, Apr. 2000. 
18. DAVIDSON, C.L.; MJÖR, I. A. Advances in glass ionomer cements. Quintessence Publishing Co., Carol Stream, 1999.

19. EWOLDSEN, N.; COVEY, D.; LAVIN, M. The physical and adhesive properties of dental cements used for atraumatic restorative treatment. Spec. care Dent., v.17, n.1, p.19-24, Jan. /Feb. 1997.

20. FEATHERSTONE, J.D.B.; ZERO, D.T. An in situ model for simultaneous assessment of inhibition of desmineralization and enhancement of remineralization. J. dent. Res., v.71, p. 804-10, Apr. 1992. Special Issue.

21. FORSS, H.; HALME, E. Retention of a glass ionomer cement and resinbased fissure sealant and effect on carious outcome after 7 years. Community Dent. oral Epidem., v. 26, n. 1, p. 21-5, Feb. 1998.

22. FORSTEIN, L. Short-and-long-term fluoride release from glass ionomers and other fluoride-containing filling materials in vitro. Scand. J. dent. Res., v. 98, n. 2, p. 179-85, Apr. 1990.

23. FRENCKEN, J.E. et al. Atraumatic restorative treatment (ART) technique: evaluation after one year. Int. dent. J., v.44, n.5, p.460-4, Oct. 1994.

24. FRENCKEN, J.E. et al. Atraumatic restorative treatment (ART): rationale, technique, and development. J. Publ. Hlth. Dent., v.56, n.3, p.135-40, 1996. Special Issue.

25. FRENCKEN, J.E. et al. Manual for the Atraumatic Restorative Treatment Approach to control Dental Caries. $3^{\mathrm{a}}$ ed, WHO Collaborating Centre for Oral Health Services Research, Groningen, 1997. 
26. FRENCKEN, J.E. et al. Three-Year survival of one-surface restorations and glass-ionomer sealants in a school oral health programme in Zimbabwe. Caries Res., v.32, n.2, p.119-26, 1998.

27. FRENCKEN, J.E.; HOLMGREN, C. Atraumatic Restorative Treatment for dental caries. Nijmegen, STI book b.v., 1999.

28. FRENCKEN, J.E.; HOLMGREN, C. How effective is ART in the management of dental caries? Community Dent. oral Epidem., v. 27, n.6, p.423-30, Dec. 1999.

29. FRENCKEN, J.E.; MAKONI, E.; SITHOLE, W.D. Atraumatic restorative treatment and glass-ionomer sealants in a school oral health programme in Zimbabwe: Evaluation after 1 year. Caries Res., v. 30, n.6, p. 428-33, 1996.

30. FRENCKEN, J.E.; MAKONI, F.; SITHOLE, W.D. ART restorations and glass-ionomer sealants in Zimbabwe; survival after 3 years. Community Dent. oral Epidem., v.26, n.6, p. 372-81, Dec. 1998.

31. FRENCKEN, J.E.; MANJI, F.; MOSHA, H. Dental caries prevalence among urban children in East Africa. Community Dent. oral Epidem., v.14, n.2, p.94-8, Apr. 1986.

32. GAO, W. et al. Comparison of atraumatic restorative treatment and conventional restorative procedures in a hospital clinic: Evaluation after 30 months. Quintessence Int., v.34, n.1, p.31-37, Jan. 2003.

33. GAO, W.; SMALES, R.J.; GALE, M.S. Fluoride release/uptake from newer glass-ionomer cements used within the ART approach. Amer. J. Dent., v.13, n.4, p.201-4, Aug. 2000. 
34. GUGGENBERGER, R.; MAY, R.; STEFAN, K.P. New trends in glassionomer chemistry. Biomaterials, v.19, n.6, p.479-83, Mar. 1998.

35. HAMP, S.E. et al. Effect of a field program based on systematic plaque control on caries and gingivitis in schoolchildren after 3 years. Community Dent. oral Epidem., v.6, n.1, p.17-23, 1978.

36. HATIBOVIC-KOFMAN, S.; KOCH, G. Fluoride release from glass ionomer cement in vivo and in vitro. Swed. dent. J., v. 15, n. 6, p. 253-8, Dec. 1991.

37. HELDERMAN, W.V. P.; MIKX, F. Priorities in oral health care in non-EME countries. Int. dent. J., v.52, n.01, p.30-34, Feb. 2002.

38. HO, T.F.T; SMALES, R.J.; FANG, D.T.S. A 2-year clinical study of two glass ionomer cements used in the atraumatic restorative treatment (ART) technique. Community Dent. oral Epidem., v.27, n.3, p.195201, June 1999.

39. HOLMGREN, C.J. ART-ODONT: an electronic network for information concerning minimal intervention techniques for caries. J. Public HIth. Dent., v.56, n.3, p.166, 1996. Special Issue.

40. HOLMGREN, C.J. Discussion from the 1998 IADR symposium: the state of ART (atraumatic restorative treatment) - a scientific perspective. Community Dent. Oral Epidem., v.27, n.6, p.454-60, 1999.

41. HOLMGREN, C.J. et al. ART restorations and sealants placed in Chinese school children - results after three years. Community Dent. oral Epidem., v.28, n.4, p.314-20, Aug. 2000.

42. HOLMGREN, C.J.; FRENCKEN, J.E. Painting the future for ART. Community Dent. oral Epidem., v.27, n.6, p.449-53, Dec. 1999. 
43. HOLMGREN, C.J.; PILOT, T. Discussion from the symposium "minimal intervention techniques for caries". J. Public Health Dent., v.56, n.3, p.161-5, 1996. Special Issue.

44. HOSOYA, Y.; GARCÍA-GODOY, F. Bonding mechanism of Ketac-Molar Aplicap and Fuji IX GP to enamel and dentin. Amer. J. Dent., v.11, n.5, p.235-9, Oct. 1998.

45. ISMAIL, A.I. Reactor paper: minimal intervention techniques for dental caries. J. Pub. HIth. Dent., v.56, n.3, p.155-60, 1996.

46. JEMT, T.; STALBLAD, P.A.; OILO, G. Adhesion of polycarboxylate-based dentalcements to enamel: an in vitro study. J. dent. Res., v.65, n.6, p.885-7, June 1986.

47. KIELBASSA, A.M.; MÜLLER, U.; GARCÍA-GODOY, F. In situ study on the caries-preventive effects of fluoride-releasing materials. Amer. J. Dent., v.12, p.13-4, Nov. 1999. Special Issue.

48. KITAJIMA, E.W.; LEITE, B. Curso Introdutório de Microscopia Eletrônica de Varredura. Piracicaba, 1999. 46 p. Manual. Escola Superior de Agricultura "Luiz de Queiroz"/ Universidade de São Paulo, Núcleo de Apoio à pesquisa.

49. KLIMEK, J. et al. Effect of a preventive program based on professional tooth cleaning and fluoride application on caries and gengivitis. Community Dent. oral Epidem., v.13, p.295-8, 1985.

50. KOMATSU, $\mathrm{H}$. et al. Caries-preventive effect of glass ionomer sealant reapplication: study presents three-year results. J. Amer. dent. Ass., v.125,n.5, p.543-9, May 1994. 
51. LIMA, J.E.O. Um plano de prevenção para consultório odontopediátrico. Rev. Gaúcha Odont., v.40, n.6, p.395-9, nov./dez. 1992.

52. LUCA-FRAGA, L.R.; PIMENTA, L.A.F. Clinical evaluation of glassionomer/resin-based hybrid materials used as pit and fissure sealants. Quintessence Int., v. 32, n.6, p.463-8, June 2001.

53. MACHADO, M. A. A. M. et al. Evaluación de pretratamientos del esmalte en la retención de un cemento de ionómero de vidrio aplicado como sellante. IN: XXXII REUNIÓN ANUAL DA SOCIDAD ARGENTINA DE INVESTIGACION ODONTOLOGICA - INTERNATIONAL FOR DENTAL RESEARCH - DIVISION ARGENTINA. Anais, Buenos Aires, IADR - Division Argentina, 1999./ Abstract n. 269/

54. MATTHESEN, M. et al. Dental health of children and adults in GuineaBissau, West Africa. Community dent. HIth., v.7, n.2, p.123-33, June 1990.

55. McKENNA, E.F.; GRUNDY, G.E. Glass ionomer cement fissure sealants applied by operative dental auxiliaries - retention rate after one year. Aust. dent. J., v.32, n.2, p.200-3, June 1987.

56. McLEAN, J.W.; GASSER, O. Glass-cermet cements. Quintessence Int., v.16, n.5, p.333-43, May 1985.

57. MCLEAN, J.W.; WILSON A.D. Fissure sealing and filling with an adhesive glass-ionomer cement. Brit. dent. J. v.136, n.7, p.269-76, April 1974.

58. MEJÀRE, I et al. Caries-preventive effect of fissure sealants: a systematic review. Acta odont. scand., v.61, n.6, p.321-330, Dec. 2003.

59. MEJÀRE, I.; MJÖR, I.A. Glass ionomer and resin-based fissure sealants: a clinical study. Scand. J. dent. Res., v.98, n.4, p.345-50, Aug. 1990. 
60. MICKENAUTSCH, S. et al. The impact of ART approach on the treatment profile in a mobile dental system (MDS) in South Africa. Int. dent. J., v.49, n.3, p. 132-8, Jun.1999.

61. MOTSEI, S.M.; KROON, J.; HOLTSHOUSEN, W.S.J. Evaluation of atraumatic restorative treatment restorations and sealants under field conditions. SADJ. V.56, n.7, p. 309-15, July 2001.

62. NAVARRO, M. F., PASCOTTO, R. C. Cimentos de ionômero de vidro Aplicações clínicas em Odontologia. Ed. Artes Médicas: Série EAPAPCD, São Paulo, 1998.

63. PEREIRA, A.C. et al. A 3-year clinical evaluation of glass-ionomer cements used as fissure sealants. Amer. J. Dent., v.16, n.1, p.23-7, Feb. 2003.

64. PEREIRA, A.C. et al. Retention and caries prevention of Vitremer and Ketac-Bond used as occlusal sealants. Amer. J. Dent., v.12, n.2, p.624, Apr. 1999.

65. PETERSSON, L.G.; TWETMAN, S.; PAKHOMOV, G.N. The efficiency of semiannual silane fluoride varnish applications: a two years clinical study in preschool children. J. Pub. Hlth. Dent., v.58, n.1, p.57-60, Winter 1998.

66. PHANTUMVANIT, $P$. et al. Atraumatic restorative treatment (ART): a three-year community field trial in Thailand - survival of one-surface restorations in the permanent dentition. J. Pub. HIth. Dent., v.56, n.3, p.141-5, 1996. Special Issue.

67. PHANTUMVANIT, P. et al. Survival of ART-sealant in 3 year community field trial. J. dent. Res., v. 77, p.972, 1998. /Abstract n. 2721/ 
68. PILOT, T. Introduction - ART from a global perspective. Community Dent. oral Epidem., v.27, n.6, p.421-2, Dec. 1999.

69. POULSEN, S. et al. The effect of professional toothcleansing on gingivitis and dental caries in children after 1 year. Community Dent. oral Epidem., v.4, p.195-9, 1976.

70. POULSEN, S.; BEIRUTI, N.; SADAT, N. A comparison of retention and the effect on caries of fissure sealing with glass-ionomer and resin-based sealant. Community Dent. oral Epidem., v. 29, n.4, p.298-301, Aug. 2001.

71. POWIS, D.R. et al. Improved adhesion of a glass ionomer cement to dentin and enamel. J. dent. Res., v.61, n.12, p.1416-22, Dec. 1982.

72. RAADAL, M.; UTKILEN, A.B.; NILSEN, O.L. Fissure sealing with a lightcured resin-reinforced glass-ionomer cement (Vitrebond) compared a resin sealant. Int. J. Paed. Dent., v. 6, n. 4, p. 235-9, Dec. 1996.

73. REUTERVING, G.K.; VAN DIJKEN, J.W.V. A three-year follow-up of glass ionomer cement and resin fissure sealants. J. Dent. Child. v.62, n.2, p.108-10, Mar./Apr. 1995.

74. SEPPÄ, L.; FORSS, H. Resistance of occlusal fissures to demineralization after loss of glass ionomer sealants in vitro. Pediat. Dent., v.13, n.1, p.39-42, Jan./Feb. 1991.

75. SERRA, M.C.; RODRIGUES JR., A.L. Potencial cariostático de materiais restauradores contendo flúor. Rev. Ass. paul. cirurg. Dent., v.52, n.5, p.359-64, set. /out. 1998.

76. SIMMONS, J.J. The miracle mixture glass ionomer and alloy powder. Tex. dent. J., v.100, n.10, p.6-12, Oct.1983 
77. SIMONSEN, R.J. Glass ionomer as fissure sealant-a critical review. J. Publ. HIth. Dent., v. 56, n. 3, p. 146, 1996. Special Issue.

78. SMALES, R.J. et al. Handling and clinical performance of a glass ionomer sealant. Amer. J. Dent., v. 9, n. 5, p. 203-5, Oct. 1996.

79. SMALES, R.J.; GAO, W. In vitro caries inhibition at the enamel margins of glass ionomer restoratives developed for the ART approach. J. Dent., v. 28, n.4, p.149-56, May 2000.

80. SMALES, R.J.; GAO, W.; HO, F.T. In vitro evaluation of sealing pits and fissures with newer glass-ionomer cements developed for the ART technique. J. clin. pediat. Dent., v.21, n.4, p.321-3, Summer 1997.

81. SMALES, R.J.; WONG, K.C. 2-year clinical performance of resin-modified glass ionomer sealant. Amer. J. Dent., v.12, n. 2, p. 59-61, Apr. 1999.

82. SONGPAISAN, Y. et al. Effects of glass ionomer cement, resin-based pit and fissure sealant and HF applications on occlusal caries in a developing country field trial. Community Dent. oral Epidem., v. 23, n.1, p.25-9, Feb. 1995.

83. SONGPAISAN, Y. et al. Mutans streptococci in a Thai population: relation to caries and changes in prevalence after application of fissure sealants. Caries Res., v.28, n.3, p.161-8, 1994.

84. STRAFFON, L.H.; DENNISON, J.B.; MORE, F.G. Three-year evaluation of sealant: effect of isolation on efficacy. J. Amer. dent. Ass., v.110, n.5, p.714-7, May 1985.

85. SUNDFELD, R.H. et al. Selante oclusal com ionômero de vidro fotopolimerizável- uma proposta altamente eficaz na prevenção da cárie dental. Âmbito odont., v.1, n.16, p. 3-7, jan./fev. 1994. 
86. TAIFOUR, D. et al. Effects of glass ionomer sealants in newly erupted first molars after 5 years: a pilot study. Community Dent. oral Epidem., v.31, n.4, p.314-9, Aug. 2003.

87. TORPA-SAARINEN, E.; SEPPÄ, L. Short-term retention of glass-ionomer fissure sealants. Proc. Fin. dent. Soc., v.86, n.2, p.83-6, 1990.

88. VELASCO, L.F.L.; NÖR, J.E.; FIGUEIREDO, M.C. Microscope evaluation of the penetration into pit and fissures of two glass ionomers used as sealants. J. dent. Res., v. 75, p.70, 1996. /Abstract n. 418/

89. WEERHEIJM, K.L; KREULEN, C.M.; GRUYTHUYSEN, R.J.M. Comparison of retentive qualities of two glass-ionomer cements used as fissure sealants. J. Dent. Child., v.63, n.4, p.265-7, July/Aug. 1996.

90. WHO/28 - 7 April 1994. Revolutionary new procedure for treating dental caries. Disponível na Internet: http://www.who.int/archieves/infpr-1994/pr94-28.html.

91. WHO: Oral Health. Disponível na Internet: Site http://www.who.int/aboutwho/en/promoting/oral.html.

92. WILLIANS, B.; WINTER, G.B. Fissure sealants: a 2-year clinical trial. Brit. dent. J., v.141, n.1, p.15-8, July 1976.

93. WILSON, A. D.; KENT, B. E. The glass-ionomer cement, a new translucent dental filling material. J. Appl. Chem. Biotech., v.21, n.11, p.313, Nov. 1971.

94. YIP, H.K. et al. Selection of restorative materials for the atraumatic restorative treatment (ART) approach: a review. Spec. care Dent., v.21, n.6, p.216-21, Nov./Dec. 2001. 
95. YIP, H.K.; SMALES, R.J. Glass ionomer cements used as fissure sealants with the atraumatic restorative treatment (ART) approach: review of literature. Int. dent. J., v. 52, n.2, p.67-70, April 2002.

96. ZIMMER, S.; ROBKE, F.J.; ROULET, J.F. Caries prevention with fluoride varnish in a socially deprived community. Community Dent. oral Epidem., v.27, n.2, p.103-8, Apr. 1999. 
ABSTRACT 


\section{ABSTRACT \\ Clinical evaluation of ART sealants in a high caries experience community}

The aim of this study was to investigate the retention and cariespreventive effect of ART sealants in newly erupted molars in a high-risk group. Seventy-four ChemFlex and seventy-six Vidrion $\mathrm{R}$ sealants were placed randomly in 42 6-8 years old patients. The sealants were placed in a school by one dentist using ART ('press finger' technique). The evaluation was carried out by 2 calibrated dentists. The lost-to-follow-up at 12 and 36 months were $9.3 \%$ and $11.7 \%$ respectively. After 12 months, $41.8 \%$ of ChemFlex and $43,8 \%$ of Vidrion were either partially or completely retained, $1,5 \%$ of ChemFlex and $1.4 \%$ of Vidrion $\mathrm{R}$ sealants were replaced by another treatment. No caries was observed in $98.5 \%$ of the sealed teeth. At 36 months evaluation, $24.6 \%$ of ChemFlex and $20.9 \%$ of Vidrion $R$ sealants were partially retained. $9.2 \%$ of ChemFlex and $9.0 \%$ of Vidrion $\mathrm{R}$ sealants were replaced by another treatment. $3.1 \%$ of Chem Flex sealed surfaces developed caries. The success rate was 93.7\%. Chi-square and Mann-Whitney tests $(p<0.01)$ showed that differences between tested materials were not statistically significant. It is concluded that although sealants showed low retention rates, sealing newly erupted first molars using ART technique may be a caries preventive measure in high-risk children. 